\title{
Internal migration and vulnerability to poverty in Tanzania
}

\author{
Rebecca Pietrelli* and Pasquale Scaramozzino $†$
}

September 2018

\begin{abstract}
This paper investigates whether migration reduced household vulnerability to poverty for a panel of households from the Kagera region in Tanzania over the period 2004-2010. The potential endogeneity of migration is controlled by both matching methods and an exogenous variation: a severe drought in 2008-09 which affected the areas of the country with a bimodal rain season, but not those with a unimodal rain season. Migration reduced vulnerability to basic needs and to food consumption poverty only for families which experienced migration to unimodal regions. The evidence supports the view that migration served as an effective risk management strategy for households.
\end{abstract}

JEL codes:

C21, I32, O15, O55

Keywords:

Migration, vulnerability, matching methods, exogenous variation, Tanzania

\section{Acknowledgements:}

We are grateful to Pierluigi Montalbano, Donato Romano, Furio Rosati and Alan Winters for very helpful suggestions. 
* Agricultural Development Economics Division, The Food and Agriculture Organization of the United Nations; rebecca.pietrelli@fao.org

$\uparrow$ School of Finance and Management, SOAS, University of London and Dipartimento di Economia e Finanza, Università degli Studi di Roma Tor Vergata; ps6@ soas.ac.uk 
According to the traditional approach, migration is motivated by the attempt by individuals to benefit from a positive expected wage gap in the region of destination relative to the region of origin. In their seminal contribution, Harris and Todaro (1970) set out a dual model of the labour market, with a traditional (/agricultural/rural) sector which pays a subsistence wage and a modern (/industrial/urban) sector where a higher marginal product of labour is achieved. Migration is the mechanism through which the labour force moves towards the more productive sectors of the economy, thereby ensuring a more efficient allocation of labour in the economy.

This traditional analysis is based on two key assumptions. First, migration is an individual decision. There is therefore no explicit consideration of the possibility that migration decisions are made at the level of the household, with some members remaining in the region of origin and some others migrating and then pooling resources with their family. Second, the decision to migrate is solely based on the expected value of the migrants' wage in the region of destination relative to the wage in the region of origin, without consideration of the risks associated with their decision.

The New Economics of Labour Migration (NELM: Stark and Bloom 1985; Stark and Levhari 1982; Oded 1991) addresses the first issue by focusing on the household as the unit where the migration decision is made. Some family members may decide to migrate in order to remit back to the original family a share of their labour income in the destination region. More generally, migration can act as an insurance mechanism, which enables the household to reduce its vulnerability to adverse shocks in the absence of fully developed insurance markets (Ray 1998, chapter 15; Bardhan and Udry 1999, chapter 8).

The role of uncertainty is increasingly seen as crucial for understanding migration decisions in low-income countries. Rosenweig and Stark (1989) show that migration associated with marital arrangements among Indian households can reduce income uncertainty and help smooth household consumption, in the presence of spatially covariant risks. More recently, the role of uncertainty on migration decisions has been studied by Burda (1995) in the context of real options theory (Dixit and Pindyck 1994). Income in both the region of origin and the region of destination is risky, and migration involves a sunk cost which cannot be recovered if the decision is reversed at a later date. Under these conditions, the option to migrate should only be 
exercised when a further delay would not be optimal: a reduction in income uncertainty in the region of destination, for instance, might lead the household to bring forward the migration decision. ${ }^{1}$ In this framework, migration can be seen as a key element of the risk management strategy by households. When income is pooled within the family, migration by some household members can be an effective tool to diversify the household's income across different sources, thereby reducing its overall risk.

In spite of its potential relevance, however, empirical analysis of the risk mitigating aspects of migration is still very limited because of the difficulty of controlling for the endogeneity of the migration decision, and because of the lack of experimental data. In this paper we are able to identify the risk reducing effects of migration thanks to an extreme meteorological event which took place in Tanzania. The country exhibits two rainfall regimes: unimodal (which covers the areas in the South, Centre and West) and bimodal (in the North, the Northern Coast and the NorthWest). The unimodal regions experience only one long rainy season in the course of the agricultural year, whereas the bimodal regions have two short rainy periods. During the 2008-09 season, the bimodal regions suffered an extreme drought. This shock affected eastern African countries and was described as "one of the worst in living memory" (IDRC 2010). Unimodal regions were, however, not affected. We look at this extreme natural event to examine how households in the region of origin were affected by the migration of household members. In particular, we analyse if migration had a different effect on the household of origin depending on whether it had been directed towards a unimodal or a bimodal region.

We adopt a stochastic outcome approach to examine how migration may have contributed to reducing household vulnerability. Specifically, we follow Chaudhuri (2000), Chaudhuri, Jalan, and Suryahadi (2002), and Günther and Harttgen (2009) and estimate the household's Vulnerability to Expected Poverty (VEP) as a measure of the effects of migration on family welfare. This approach to the analysis of household poverty is intrinsically dynamic and forward-looking, since vulnerability is defined as the probability that the household might fall below a critical poverty line as a result of unfavourable shocks. The approach is also consistent with the World Bank's "Social

\footnotetext{
${ }^{1}$ See also Khwaja (2002), Anam, Chiang, and Hua (2008), Moretto and Vergalli (2008) and Vergalli (2011) for applications of the real options approach to migration. Abel et al. (1996) develop a general approach to the analysis of investment under uncertainty.
} 
Risk Management" framework, which regards the ability of a community to manage risks as the main source of vulnerability (WB 2005).

We use a comprehensive data set from surveys carried out over the period 20042010 in the region of Kagera in Tanzania. Individual household members are traced over time, and the area of destination of migrants is recorded alongside information about both the original family and the new family in the destination region. It is thus possible to measure changes in the vulnerability of the original household in a fully dynamic setting. Specifically, we examine whether households whose members had migrated to a unimodal region of the country experienced a reduction in their vulnerability to expected poverty relative to households whose members had migrated to a bimodal region, which was affected by the drought. An ex ante unanticipated shock would have resulted in changes in the ex post vulnerability of the household.

The main empirical results are consistent with migration as an insurance mechanism for the household. We first adopt a matching approach to examine the differential changes in the vulnerability to basic needs and food insecurity by households with and without migrants, and show that migration by some family members to unimodal regions significantly reduced the vulnerability of the household of origin. We then exploit the "natural experiment" of the drought in the bimodal meteorological regions in Tanzania to control for time-varying unobserved heterogeneity, and observe that migration to the drought-free unimodal zones resulted in a significant decline of vulnerability for the household of origin. These novel empirical results show that migration did enable households to mitigate their risks.

Our results are consistent with Hirvonen and Lilleør (2015) and De Weerdt and Hirvonen (2016), who used the same data set for Kagera. Hirvonen and Lilleør (2015) establish the existence of links between migrants and their home communities, both during the migration spell and following return migration. De Weerdt and Hirvonen (2016) find evidence that migrants feel an obligation towards family members who remain at home, consistent with social norms associated with kinship (Lévi-Strauss 1969). Stayers benefit from the migrants' positive shocks and receive some insurance against their own negative shocks, but do not suffer from the migrants' negative shocks.

The structure of the paper is as follows. Section 2 provides background information on the Kagera region and on the severity of the drought of 2008-09. Section 3 describes the household sample data used in the analysis and motivates our 
choice of measure of vulnerability. Section 4 illustrates the matching approach adopted in the paper and discusses the empirical results of the analysis. Section 5 explains our methodology for the exogenous variation and shows that migration to unimodal zones resulted in a significant decline in vulnerability for the households of origin. Section 6 concludes.

\section{The Kagera region and the drought of 2009}

Kagera is the remote north-western region of Tanzania, bordering Lake Victoria, Rwanda, Burundi and Uganda. The region covers $40,838 \mathrm{~km}^{2}$ of land surface and $11,885 \mathrm{~km}^{2}$ of water surface and is overwhelmingly rural. According to the latest Population and Housing Census (2012), the population residing in the region is about 2.5 million. The main ethnic groups of the region are the Haya and Nyambo tribes in the north, and the Subi, Sukuma, Zinza and Hangaza tribes in the south.

The agricultural sector is dominant in the Kagera economy. The sector accounts for about 50 percent of the regional GDP, and employs about 90 percent of the economically active population in the production of food and cash crops. Bananas, beans, maize and cassava are the main food crops while coffee, tea and cotton are the main cash crops. Livestock is the second most important economic activity in the region. Recently, fishing in Lake Victoria has provided an alternative source of income. The industrial base in the region is limited and mainly comprises agro-industrial operations (URT 2012). The region is relatively remote and is the farthest of the country from the political and commercial capital, Dar es Salaam.

Tanzania presents two distinct rainfall regimes. The country is accordingly divided into a unimodal zone (covering the south, central and west regions of the country) and a bimodal zone (extending over the north, northern coast and north western areas), as shown in Figure 1. The two zones have different rainy seasons and consequently also different harvesting periods. The unimodal zone experiences only one long rainy season from December to April: sowing takes place in November and harvesting in June and July. The bimodal zone has short rainy seasons from October to December and a long rainy one from March to May. It has a short harvesting period in January/February and a long one in July/August (WFP 2013). As shown in Figure 1, the Kagera region falls in the bimodal rainfall regime. 
In 2009, a severe drought hit many countries of East Africa, leading to crop failures and mortality of livestock (Goldman and Riosmena 2013). The northern regions of Tanzania were extremely damaged by the drought of 2009 (Goldman and Riosmena 2013), and Kagera was one of the worst hit regions..

\section{Insert Figure 2 here}

As supported by the FAO GIEWS ${ }^{2}$ data used for measuring rainfall anomaly (Figure 2), the regions under the bimodal rainfall regimes received a significantly lower amount of rain in 2009 compared to the rain received in the long-term. As suggested by the meteorological literature, one of the simplest way to measure the precipitation anomaly is to use the difference between the annual observation and the long-term mean. ${ }^{3}$ As expected, the bimodal regions report a negative difference between the $\mathrm{mm}$ of rain received in 2009 and those received in the previous five years as well as in the previous ten years. These data confirm the severity of the drought experienced by regions with bimodal regimes. By contrast, the unimodal regions of Tanzania report a slight increase of (average) rainfall received in 2009 compared to the previous period.

\section{Data}

\subsection{Sample of households}

The Kagera Health and Development Survey (KHDS) was designed and implemented by the World Bank and the Muhimbili University College of Health Sciences. It consists of a survey of households living in Kagera region, originally interviewed in four rounds from 1991 to 1994 (KHDS I). Resurveys were then administered in 2004 (KHDS II) and 2010 (KHDS III) with the aim of re-interviewing all individuals who were interviewed in any round of the KHDS I, the so called Previous Household

\footnotetext{
${ }^{2}$ The FAO - Global Information and Early Warning System collects various information by utilizing remote sensing data. More information is available here: http://www.fao.org/giews/data-tools/en/

${ }^{3}$ Keyantash and Dracup (2002) review and compare the drought indices.
} 
Members (PHHMs). ${ }^{4}$ The analysis in the present paper employs KHDS II and III. Nevertheless, the very low attrition rate in both waves preserves the representativeness of the survey. In KHDS II the rate of re-contacted original households is 93 percent while in KHDS III it is equal to 92 percent of the KHDS I household sample. Taking into account the cases of original households those members were found to be dead in 2004 (17 cases in KHDS II) and in 2010 (26 in KHDS II), the number of untraced households is extremely low: 63 households in the KHDS II and 71 in the KHDS II. This impressive result can be explained by the fact that one of the feature of this survey was to trace households irrespective to their location. ${ }^{5}$

For the purposes of the present analysis, the 2004 sample of households is restricted to those residing in the original community $(1,083)$. This allows us to compare households with and without migrants living in the same place (the original community) between 2004 and 2010. Our choice is motivated by: (i) shortening the period of the analysis to the shortest one possible (2004-2010) $)^{6}$ since a vulnerability analysis is more appropriate over a short time period; (ii) focusing the analysis on the periods right before and after the drought to exploit this exogenous variation (see section 5); (iii) ruling out the effect of previous migration of the entire households since, for households that moved between 1991 and 2004, it is not possible to identify the presence of migrant members between 2004 and 2010. ${ }^{7}$ The selected 2004 sample of households residing in the original community is poorer than the sample of households who were able to move between 1991 and 2004 both in terms of food consumption and non-food consumption (Beegle, De Weerdt, and Dercon 2011, page 1014). This means focusing our analysis on the effect of having migrants for poorest households of the Kagera region. Following from this, a note of caution should be raised concerning the external validity of our findings. The exclusion of the migrant

\footnotetext{
${ }^{4}$ The baseline KHDS I sample is composed of 915 households. In 2004, the field team managed to re-contact 832 households of the baseline sample. Re-contact means that at least one PHHM was re-interviewed in the KHDS II. Because after thirteen years a number of people had moved out of their original households, the new sample consisted of 2,774 households. In 2010, 818 households from KHDS I sample were re-contacted. After 18 years, the new sample of households included 3,313 households compared to the original 915 (De Weerdt et al. 2012).

${ }^{5}$ In KHDS II the 49 percent of the households were found in the same village of the original household (Beegle, De Weerdt, and Dercon 2011) while in the KHDS III the 44 percent of households (De Weerdt and Hirvonen 2016).

${ }^{6}$ Other possible options would have been to compare: (i) households with and without migrants living in the same place between KHDS I (1991) and II (2004); (ii) households with and without migrants living in the same place between KHDS I (1991) and III (2010). In both cases, the time period of the analysis would have been longer and less appropriate for a vulnerability analysis.

${ }^{7}$ In fact, focusing on the entire 2004 sample would not allow to establish whether they have members who moved between 2004 and 2010, since localization is reported with respect to KHDS I.
} 
households (between KHDS I and II) hampers our ability to derive consistent estimates for the entire population.

The presence of household split-offs between 2004 and 2010 needs to be taken into consideration. The present analysis has been conducted on two samples of households: the extended sample of 1,238 households including all the splits at 2010, as well as the restricted sample of 881 households with the same head in the two periods. This implies testing the impact of migration on the entire network of the households. The latter is in the same spirit as Angelucci et al. (2010). Indeed the intergenerational family ties between new households of siblings (living together in the previous wave) are considered to form the extended sample. The summary statistics are reported in Table A1 in the Appendix for the two samples and by typology of households, with and without migrants.

To define the migrants this paper looks at the household members' localization in 2010 compared to 2004 (which, according to the selected sample of households, corresponds to the original localization in KHDS I). The migrant can be localized in a nearby village, elsewhere in the same region, or elsewhere in Tanzania. The paper adopts the definition of migration proposed by Beegle, De Weerdt, and Dercon (2011) and De Weerdt and Hirvonen (2016), according to which a migrant is a household member found not to reside in the baseline community at the end of the sample period in 2010. The sub-sample of individuals (specifically PHHMs) who moved during the period considered is composed of 197 people and is balanced in terms of gender difference (53 per cent of migrants are females). Since the analysis focuses on internal migration, 62 international migrants are not considered in the analysis. ${ }^{8}$ The choice of focusing on internal migration allows us to contribute to this emerging literature. From the seminal work on internal migration in developing countries by Lucas (1997), the debate on the implications of internal migration for poverty alleviation and development has grown but there is still a lack of "adequate knowledge on the benefits gained from internal migration" (Vargas-Lundius 2018). On the other hand, the effect of international migration have been extensively investigated (see Ratha et al. 2016 for a recent review of the benefits of international migration for both destination and origin countries) and have been shown to be larger compared to internal migration (for

\footnotetext{
${ }^{8}$ By the sampling design, some individuals are not traced between 2004 and 2010; if they are not PHHMs, namely they are new members in 2004, or they are not found to reside with a PHHMs at 2010). Additionally, due to the scope of the analysis, entire households migrating between 2004 and 2010 are not considered in the analysis.
} 
example Castaldo et al. (2012) and McKay and Deshingkar (2014) show that international migrants remit more and to richer households). If some selectivity bias may derive from the choice of our sample of analysis, it should be noted that we are focusing on the poorest left-behind households who are able to engage their members in internal migration only.

One of the main limitations of the dataset employed is the lack of detailed information on remittances. The household questionnaire for 2010 does not ask questions on the amount of remittances received by the origin households. The only information on remittances is asked indirectly in the modules on shocks (if current or past years have been good or bad for respectively high remittances or low remittances) and on household activities and income (whether received remittances are the first, second or third most important income source for satisfying the household daily needs).

Finally, this analysis uses two additional datasets provided by the Economic Development Initiatives (EDI) Group. ${ }^{9}$ First, the total, food, and non-food consumption data for all the waves have been used in the analysis. Consumption data are expressed in annual per capita terms deflated using information from the KHDS price questionnaire. Second, we control for migration distance by means of a distance matrix, elaborated by Jose Funes and Jean-Francois Maystadt. The matrix contains all distances between all households interviewed in KHDS III. The distances are expressed using the Euclidean metrics $(\mathrm{km})$.

\subsection{Outcome variable}

This paper follows the Vulnerability to Expected Poverty (VEP) approach proposed by Chaudhuri, Jalan, and Suryahadi (2002), and extended by Günther and Harttgen (2009) to take into account idiosyncratic and covariate shocks. They define vulnerability as "the ex-ante risk that a household will, if currently non-poor, fall below the poverty line, or, if currently poor, will remain in poverty". According to this definition, a household is classified as vulnerable if it has a high probability of being poor in the future. Conversely, a household is classified as not vulnerable if it is not likely to be poor in the future. Formally, the vulnerability level of a household $i$ at time $t$ is defined as the probability that the household will find itself consumption poor at time $t+1$ (Chaudhuri Jalan, and Suryahadi 2002).

\footnotetext{
${ }^{9}$ Additional information on the EDI Group and specifically on KHDS data can be found here: http://edi-global.com/publications/.
} 
The VEP measure presents two main attractive features. First, it estimates vulnerability using a single round of cross-sectional data. Second, it is easily interpretable since the results are expressed in terms of the expected value of Foster, Greer, and Thorbecke's (1984) measure of poverty. The VEP measure, generally recognized as one of the fundamental approaches for measuring vulnerability (Gallardo 2017), has been extensively used in the empirical literature, either as the outcome of interest (Swain and Floro 2012; Cahayadi and Waibel 2016; Nguyen, Raabe, and Grote 2013; Imai 2011; Swain 2012; Magrini and Vigani 2016; Khandker 2007; Rayhan and Grote 2007; Imai, Gaiha, and Thapa 2015; Zereyesus et al. 2017), or for testing the link between vulnerability and poverty (Adepoju et al. 2011; Feeny and McDonald 2015; Imai, Gaiha, and Kang 2011; Jha and Dang 2011).

Following the statistical approach proposed by Chaudhuri, Jalan, and Suryahadi (2002), we assume that consumption is log-normally $\left(\ln \left(c_{i}\right)\right)$ distributed across households and compute VEP measure as the estimated probability $(\widehat{P r})$ that a household with the characteristics $X_{i}$, will be poor as:

$$
\begin{aligned}
V_{i} & =\widehat{P r}\left(\ln \left(c_{i}\right)<\ln (z) \mid X_{i}\right) \\
& =\Phi\left(\frac{\ln (z)-X_{i} \widehat{\beta}}{\sqrt{X_{i} \widehat{\theta}}}\right)
\end{aligned}
$$

where $\Phi$ denotes the cumulative density of the standard normal random variable while $X_{i} \widehat{\beta}$ and $X_{i} \hat{\theta}$ are respectively the estimates of the mean and of the variance of $\log$ consumption, obtained from a three-step feasible generalised least squares (FGLS) procedure.

Despite its attractive features, the limitations of the VEP approach are well known in the empirical literature (Gallardo 2017). The method relies on strong simplifying assumptions. These require that the probability distribution is: (i) lognormal; (ii) the same for all the units in the population; (iii) invariant in the future (cross-sectional variability proxies inter-temporal variance in consumption); and (iv) based on a set of observable characteristics. Despite the assumptions used for the estimation of the probability distribution being quite restrictive, there are no specific reasons why they should be valid only for those households with or for those households without migrants. In other words, the (i) log-normality, (iii) time- 
stationarity, and (iv) conditionality assumptions are not expected to interfere with the migration status of the households' members and therefore with the empirical strategy proposed to assess the effect of migration on vulnerability. On the other hand, the assumption (ii) that the same probability distribution is estimated for households with and without migrants is required in order to smooth any difference detected in the two samples of households.

Additionally, as first pointed out by Hoddinott and Quisumbing (2003), the VEP method has the undesirable feature that the probability of the household being poor decreases when the variability of household consumption around the poverty line increases: in a nutshell the vulnerability is reduced by assigning the household more risk. This undesirable feature is particularly problematic because it is in contrast with the evidence of the poor being more risk averse. Gallardo (2017) illustrates this shortcoming by using an example: if two households have the same expected value of consumption but different variances, the household with less dispersion in its consumption outcomes results the more vulnerable. ${ }^{10}$ On the contrary, the household with very dispersed welfare outcomes results to be less vulnerable. In contrast to the previous simplifying assumptions, this shortcoming of the VEP approach can be problematic in that it specifically applies to one of the two samples of households considered in the analysis. According to the NELM literature, households with migrants are expected to have less consumption variance because of risk pooling. Therefore, as in the example from Gallardo (2017), the VEP approach perversely considers them to be more vulnerable than households with more variance, as the household-less migrants are supposed to be. This means that, if any effect on vulnerability is detected by using the VEP approach, this can be considered as a lower bound. In fact, a greater difference between households with and without migrants should be reported if low consumption variance would be translated in less vulnerability - rather than more vulnerability.

The VEP measure has been estimated in 2004 and 2010 for all households which did not move relative to their initial location reported in KHDS I. Table A2 in the Appendix shows the results for total and food consumption models using the FGLS procedure (last step estimations). All coefficients display the expected signs. For

${ }^{10}$ Gallardo (2017, page 19) uses a figure to represent the probability density of consumption of two people with the same expected value of consumption, which is equal to 0.8. "Person A is better off because she has less dispersion (less variance) in her probable consumption outcomes. However, under the VEP approach, she is more vulnerable than person B because her probability of being poor is greater". 
example, the age of household head has a concave impact on food consumption. The proportion of adults of the household has a positive impact on consumption, while the number of children has a negative effect.

As shown in Table 1, the vulnerability rates in 2010 are greater than the poverty rates, for both samples and measures. Beside the vulnerability rates, Table 1 presents the estimated expected means and variances of total and food consumption, as well as the vulnerability means. The mean estimates are similar in magnitude for the two groups of households with and without migrants (respectively 0.41 and 0.43 for basic needs poverty and 0.34 and 0.36 for food poverty) and the hypothesis of their equality in both cases cannot be rejected by a $t$-test of equality of vulnerability means. The same pattern is confirmed in the case of food and basic needs poverty.

\section{Insert Table 1 here}

Finally, Table 2 reports the vulnerability variation between 2004 and 2010 for (both extended and same head) households with and without migrants. In the period considered, households with migrants perform better in terms of vulnerability reduction than households without them, both for basic needs and food poverty. For both samples the vulnerability to food poverty decreases in 2010 relative to 2004, while for households without migrants it increases. The vulnerability to basic needs poverty decreases in the extended sample for households without and with migrants, but for the latter the decline is larger. The difference of the vulnerability variation between household with and without migrants is statistically significant for basic needs poverty in the extended household sample and for food poverty in the sample of households with the same head.

Insert Table 2 here

\section{$4 \quad$ Matching approach}

\subsection{Methodology}


It is well-known in the development literature ${ }^{11}$ that the estimation of the impact of migration on the households of origin (or on the migrants) is made difficult by the issue of endogeneity. ${ }^{12}$ Specifically, the outcomes of households with and without migrants are not simply comparable to each other because households self-select into migration. In fact, both observed and unobserved attributes of households are likely to be correlated with the decision to send one member away as well as with the outcome of interest, which in our case is the household's vulnerability to poverty. We propose a valuable approach that allows us to assess the effect of migration without randomised data.

To assess the impact of migration on vulnerability to poverty of origin households, we first consider the following model:

$$
A T T=\left[Y_{t}-Y_{t^{\prime}} \mid X_{t^{\prime}}, D=1\right]-\left[Y_{t}-Y_{t^{\prime}} \mid X_{t^{\prime}}, D=0\right]
$$

where $A T T$ is the Average Treatment of the Treated. The treatment variable (dummy $D$ ) is equal to 1 if the household had any migrant members between the baseline period $\left(t^{\prime}=2004\right)$ and the following interview $(t=2010)$. The outcome of interest is the variation in the vulnerability to expected poverty (VEP) by the household between the first (2004) and the second period (2010). The VEP variation is measured both in terms of basic needs and food poverty. The main advantage of this method is that it allows for "temporally invariant differences in outcomes between households with and without migrants" (Smith and Todd 2005). Some household attributes which are unobserved to the researcher, such as loss aversion, entrepreneurial ability or the strength of family ties, may play an important role for migration. For instance, a loss averse household may be reluctant to encourage migration of its members, when this is perceived as a risky strategy. ${ }^{13}$ The household may also be reluctant to engage in crop diversification, which may be a useful risk-management strategy against agricultural production risks. On the other hand, a household engaged in crop diversification may reduce its exposure to agricultural product risk, thereby also reducing the gains from migration. In other

\footnotetext{
${ }^{11}$ Following McKenzie (2015), while the development literature aims at estimating the impact of migration on welfare of their migrants and of their families of origin, the immigration literature focuses on the impact of migration on the outcomes of natives in the destination country.

${ }^{12}$ See McKenzie and Yang (2010) for a very exhaustive explanation.

${ }^{13}$ For the concept of loss aversion and its difference from risk aversion see Kahneman and Tversky (1979, 1991).
} 
words, our matching method controls for the selection into having migrants due to time-invariant unobservable characteristics at household level.

The model is estimated using a variety of matching estimators. We first use the difference-in-difference with propensity score matching method ${ }^{14}$ (D-i-D PSM) proposed by Smith and Todd (2005). In order to obtain the propensity score we estimate a logit model ${ }^{15}$ that links the probability of having a migrant in $t$ to household characteristics in $t^{\prime}$. The model is defined as :

$$
P\left(D_{i, j, t}=1\right)=F\left(X_{i, j, t}, Z_{j, t}\right)
$$

The dependent variable is the probability that household $i$ in village $j$ has a migrant member in period $t^{\prime}$. The binary dummy $D_{i, j, t}$, equals one if household $i$ has at least one migrant in period $t$ and zero otherwise. The probability of having a migrant member is a logistic function $(F)$ of household characteristics measured at $t$.

Second, we employ the bias-adjusted estimator proposed by Abadie and Imbens (2006) to estimate the Average Treatment on Treated (ATT). The main advantage of this estimator is that it allows for matching on multiple covariates without imposing parametric assumptions. According to Gibson, McKenzie, and Stillman (2011) and Gibson, McKenzie, and Stillman (2013), the bias-adjusted matching estimator of Abadie and Imbens (2006) performs next best after the instrumental variable (IV) estimator among the non-experimental methods. IV estimation has been avoided in the analysis because of the nature of the dependent variable, which makes the exclusion restriction unlikely to hold. ${ }^{16}$

Third, the Coarsened Exact Matching (CEM) estimator recently developed by Iacus, King, and Porro (2011) has been employed. After pre-processing the data, the

\footnotetext{
${ }^{14}$ The D-i-D PSM estimator requires that:$$
\mathbb{E}\left(Y_{0, t}-Y_{0, t^{\prime}} \mid P, D=1\right)=\mathbb{E}\left(Y_{0, t}-Y_{0, t^{\prime}} \mid P, D=0\right)
$$

where $t^{\prime}$ and $t$ are respectively the time periods after and before migration; $Y_{0}$ is the potential outcome of households with and without migrants, and $P=\operatorname{Prob}(D=1 \mid Z)$ is the conditional probability that there is a migrant in the family. Furthermore, this estimator requires that the support condition holds in both periods $t$ ' and $t$ : for all the observable conditioning variables Z, there must a positive probability of having $(D=1)$ or not $(D=$ 0) migrants.

${ }^{15}$ We obtain similar results by using a Probit model. The results are presented in Table A3 of the Appendix.

${ }^{16}$ McKenzie and Yang (2010) caution against the use of IV to estimate the impact of migration.
} 
vulnerability variation (both for basic needs and food poverty) has been regressed on a migration dummy equal to one if the household had at least one member who migrated between 2004 and 2010, and zero otherwise.

The key element of this strategy is to match households with migrants to those without them with similar pre-treatment characteristics measured in 2004. We specifically avoid matching on characteristics in 2010 because they may be endogenous to migration. ${ }^{17}$ The attributes used to match households are aimed to control for the propensity of having migrants in the following years (household size; number of males; number of members with primary education; number of members with secondary education; a dummy for whether the origin household is living in urban Bukoba; number of cattle owned by the household; number of sheep owned by the household; acre of plots owned by the household; dummy for having a bank account, dummy for having experienced a shock; dummy for participating in informal organizations). For example, the amount of assets owned by a farmer household is an observable characteristic which can be correlated both with migration and with vulnerability to poverty. Indeed, the household may decide to sell part of its assets to cover the migration costs. On the other hand, the household may decide to sell some assets after the occurrence of a negative shock as part of a strategy of consumption smoothing, which will in turn affect the probability of the household experiencing consumption below the poverty line.

\subsection{Results}

As described above, matching has been obtained over pre-treatment covariates in 2004 . These are related to household demographic characteristics which affect the propensity of having migrants and the risk management strategy. The inclusion of a relatively large number of covariates is motivated by the need to satisfy the Conditional Independence Assumption, i.e. that there are no other observable factors influencing migration and the potential outcomes that would be obtained in the absence of migration. The balance test is satisfied for all the used covariates for the two samples of households. After matching, baseline variables for the treatment group are well

\footnotetext{
17 This was the approach followed by Esquivel and Huerta-Pineda (2007) to assess the effect of remittances on poverty of Mexican households: see also McKenzie and Yang (2010).
} 
balanced in both samples (see the $p$-values for matched and unmatched households in Table A4 of the Appendix).

Before looking at the results, Figure A1 in the Appendix confirms the common support condition for propensity score matching. The evidence suggests that the large majority of observations are found to be on common support, hence they can be compared in a meaningful way.

\section{Insert Table 3 here}

Table 3 reports the results from all the matching methods employed: propensity score (matching to the nearest neighbour, with the Caliper of $0.2 \%$ and Kernel), matching on multiple covariates (with three different distance metrics: Mahalanobis, Euclidean, and the inverse variance), and coarsened exact matching. The results are presented for both samples of households, in columns (a) and (c) for vulnerability to basic needs poverty and in columns (b) and (d) for vulnerability to food poverty.

The common result which emerges from these findings is that in 2010 households with migrants were, on average, less vulnerable to poverty than households without migrants compared to 2004. The estimated significant gain from the presence of migrants is a reduction in vulnerability to expected poverty, ranging from 0.09 to 0.15 points for vulnerability to basic needs in the sample of extended households (column a); and from 0.12 to 0.26 points for vulnerability to food poverty in the sample of households with the same head (column d), accordingly to the different method employed.

An interesting finding is that the results are specular for the two samples of households. While for extended households the migration effect is significant for vulnerability to basic needs poverty (column a) but not for food poverty, for households with the same head in the two periods there is a stronger significant effect for food poverty (column d). This result may be driven by the fact that households with the same head may have members with a higher average age since the younger members may have left the original household. ${ }^{18}$ They are thus more likely to be poorer than households resulting from split-offs, as it emerges by the average higher values of food and total consumption for extended households with migrants (Table A1), and may

\footnotetext{
18 The average age of the head of extended households with migrants is 50 while for the sample of households with the same head with migrant is 59 (Table A1).
} 
face barriers to migration. Consequently, whenever they can invest in migration, households with the same head will have a stronger return in terms of reduced vulnerability to food poverty. These results are consistent with Skoufias and Quinsumbing (2003), who argue that food consumption tends to be given a higher priority in terms of different informal insurance arrangements at the community level relative to non-food consumption.

\section{Exogenous variation}

The results from the matching analysis of the previous section are valuable because they allow us to assess the effects of migration even without randomised data. These results may however still be affected by time-varying unobserved heterogeneity across households. In order to control for this, our analysis takes advantage of a natural event: the drought in the bimodal regions of Tanzania in 2008-09. As discussed by Rosenzweig and Stark (1989), the covariance of shocks between the area of destination, where migrants live, and the place of origin, where their households reside, has a crucial relevance for risk-management. They find that migration contributed to the reduction in the variability of consumption of the household of origin, controlling for the variability of household income from crop production. Furthermore, they find that "households exposed to higher income risk are more likely to invest in longer-distance migration-marriage arrangements" (Rosenzweig and Stark 1989).

The crucial assumption tested in our work is that migration to unimodal zones of the country acted as an insurance mechanism for the households of origin against the effects of the extreme drought. Those migrants who moved from Kagera to unimodal areas of Tanzania can be expected to have been less damaged by the drought than their household of origin. They will therefore have been better able to send remittances back to Kagera region. ${ }^{19}$ Thus, in the subsample of households with migrants, those with members who migrated to the unimodal areas of the country should have become less vulnerable than households with migrants in the bimodal areas. This exogenous

\footnotetext{
${ }^{19}$ This is confirmed by the relevance of received remittances for origin households' daily needs by to migrants' localization. Only 1.63 percent of households with migrants in bimodal areas consider remittances as the most important income source for meeting their daily needs while 6.67 percent of households with migrants in unimodal areas consider the received remittances as the most important income source. The same pattern is confirmed for the percentages of households ranking remittances as the second most important source of income: 4.25 percent for households with migrants in bimodal areas and 6.67 percent for households with migrants in unimodal areas. The same for the third income source: 3.13 percent for households with bimodal migrants and 7.69 percent for households with unimodal migrants.
} 
variation (the extreme drought) negatively affected, ceteris paribus, the households living in Kagera. If households with migrants in unimodal areas are found to perform better in their vulnerability variation than households with migrants in bimodal areas, this can be seen as evidence that migration acted as an effective risk management strategy.

The focus on the sub-sample of households with migrants allows us to control for unobserved heterogeneity. In fact, households with migrants in unimodal zones are not expected to be structurally different from households with migrants in bimodal areas of the country. A range of $t$-tests on the observable characteristics (Table A5 in Appendix) confirm the balance between households with migrants in unimodal areas and households with migrants in bimodal areas. The balance in the observable characteristics supports the presence of a balance in unobserved heterogeneity.

In order to exploit this exogenous variation, we limit the analysis to the subsample of households having at least one migrant in 2010. Thus the focus is on the impact of migrants' location on the change of vulnerability to poverty of the household of origin before (2004) and after (2010) the drought. Formally, the following equation is estimated:

$$
\Delta V u l_{i}=\beta_{0}+\beta_{1} \text { Dist }_{i}+\beta_{2} \operatorname{Unim}_{i}+\beta_{3} \text { Dist }_{i} * \operatorname{Unim}_{i}+\beta_{4} \Delta X_{i}+\varepsilon_{i}
$$

The focus on changes over 2004-2010 in household vulnerability to poverty $\left(\Delta V u l_{i}\right)$ and attributes $\left(\Delta X_{i}\right)$ allows to purge the estimates of household time-invariant heterogeneity. Dist $_{i}$ measures the distance (in $\mathrm{Km}$ ) between the migrant and his family of origin. Living closer to the original family may facilitate the reception of remittances, cash and particularly in-kind transfers. The model adopts the linear elasticity form for the distance between migrants' new location and origin families following the literature studying the destination choices among migrants. ${ }^{20}$ The key variable of this specification is the dummy variable Unim $_{i}$ that which is equal to one if the migrant from household $i$ is located in a unimodal zone and zero otherwise. Finally, Dist $_{i} * \operatorname{Unim}_{i}$ is an interaction term between the distance and the unimodal dummy. The interaction controls for the potential different effect of migration to unimodal areas depending on the distance which separates migrant and household of origin.

\footnotetext{
${ }^{20}$ From the seminal paper by Schwartz (1973) to the recent paper by Ingelaere et al. (2018) using the KHDS data.
} 
If the household has more than one migrant, the Dist $_{i}$ variable is replaced with the mean distance over all migrants. In this case, the unimodal dummy is equal to one if at least one migrant moved to unimodal areas of the country. Table A6 in the Appendix reports the summary statistics of variables used.

Table 4 reports the impact of migrant location on the change in household VEP, before (2004) and after (2010) the occurrence of the drought, for the sub-sample of households with migrants.

\section{Insert Table 4 here}

The distance coefficient is not statistically significant. This can be explained by the low relevance of the distance variable when controlling for the migration to unimodal areas. Furthermore, migrants in the unimodal areas are closer to original families (Table A5). By contrast, the coefficient on the unimodal dummy is highly negative and statistically significant: it translates into a reduction of about 0.42 vulnerability points for basic needs and 0.55 vulnerability points for food. Its effect declines with the distance from the area of origin as indicated by the positive coefficient on the interaction term, though this is only significant for vulnerability to food poverty. The unimodal and the interaction coefficients are however jointly significant in both cases: the $p$-value for the $F$ test is 0.0880 for vulnerability to basic needs poverty (column a) and 0.0476 for food poverty (column b).

We can obtain an estimate of the average effect of the unimodal location of migrants on vulnerability to poverty change by considering the mean value of the Distance variable in the sample, which is $\mathrm{km} \mathrm{249.} \mathrm{At} \mathrm{the} \mathrm{mean} \mathrm{distance,} \mathrm{the} \mathrm{effect} \mathrm{is}$ $0.42+0.0002 \times 249=0.37$ for vulnerability to basic needs poverty and $0.55+0.0006$ $\times 249=0.40$ for vulnerability to food poverty. Migration of family members to unimodal zones of Tanzania is thus associated, on average, with a differential decrease in vulnerability for the household of origin of about 0.40 vulnerability points relative to its pre-shock level.

It is interesting to observe that, for households with the same head, when we explore the effects of the exogenous variation the presence of migrants to unimodal zones significantly reduces their vulnerability both to basic needs and to food poverty. By contrast, the matching methods of section 4 do not show a significant reduction to vulnerability to basic needs (Table 3). This different result may be due to the fact that 
matching methods may not fully capture some of the time-varying characteristics that can instead be controlled for in an analysis that exploits the exogenous variation due to the natural event. An example of time-varying unobservable characteristic can be the variation over time of the informal household network, namely the pool of friends and associations the household can rely on after the occurrence of the drought. On the contrary, the matching method may underestimate the effect of migration by comparing households with migrants with households who rely on alternative coping strategies, unobservable and time-varying. Controlling for the latter, the approach relying on the exogenous variation allows us to compare households with and without migrants to unimodal areas, having, for example, the same type of informal network variation in response to the drought.

\section{Conclusions}

Migration can be an important strategy to reduce the risks faced by households, but empirical evidence on the risk mitigating aspects of migration is still limited. This paper investigates how vulnerability to expected poverty was affected by migration from the Kagera region of Tanzania. The paper uses matching methods and exploits an exogenous variation due to an unanticipated drought which only affected regions with a bimodal rainy pattern. The empirical findings show that vulnerability to expected poverty was significantly reduced for families whose members migrated to unimodal regions, relative to those with migration to bimodal regions. After controlling for timevarying unobservable factors, we find an effect of migration on vulnerability to basic needs as well as on vulnerability to food poverty of origin households. The evidence, therefore, supports the view that migration acted as an effective risk management strategy for households. We did not enquire as to why this could be the case as this would demand more information about the channels, since migrant remittances and other important personal characteristics of migrants are not available. Our results are however consistent with the findings by De Weert and Hirvonen (2016), who show that the presence of migrants provides insurance to the family members who remain at home.

Additionally, a future extension of this research would be to explore further the ex ante cost of migration as a risk management strategy. In fact, in the absence of shocks, migration could have a high cost for the origin households which is not 
compensated by higher returns. Finally, resorting to migration could have an opportunity cost in terms of alternative strategies, such as for example crop diversification that could instead be adopted by origin households. This is an important line of research which would be worth exploring in the future. 


\section{The authors declare that they have no competing interests.}

\section{References}

Abadie, Alberto and Guido W. Imbens. 2006. "Large sample properties of matching estimators for average treatment effects." Econometrica 74 (1): 235-267.

Abel, Andrew B., Avinash K. Dixit, Janice C. Eberly, and Robert S. Pindyck. 1996. "Options, the value of capital, and investment." Quarterly Journal of Economics 111 (3): 753-777.

Adepoju, Abimbola O., Sulaiman A. Yusuf, Bolarin T. Omonona, and Foluso Y. Okunmadewa. 2011. "Vulnerability profile of rural households in South West Nigeria." Journal of Agricultural Science 3 (1): 128-139.

Anam, Mahmudul, Shin-Hwan Chiang, and Lieng Hua. 2008. "Uncertainty and international migration: an option cum portfolio model." Journal of Labor Research 29 (3): 236-250.

Angelucci, Manuela, Giacomo De Giorgi, Marcos A. Rangel, and Imran Rasul. 2010. "Family networks and school enrolment: Evidence from a randomized social experiment." Journal of Public Economics 94 (3): 197-221.

Bardhan, Pranab and Christopher Udry. 1999. Development microeconomics, Oxford, Oxford University Press.

Beegle, Kathleen, Joachim De Weerdt, and Stefan Dercon. 2011. "Migration and economic mobility in Tanzania: Evidence from a tracking survey". Review of Economics and Statistics 93 (3): 1010-1033.

Burda, Michael C. 1995. "Migration and the option value of waiting". Economic and Social Review 27: 1-19.

Cahyadi, Eko Ruddy and Hermann Waibel. 2016. "Contract farming and vulnerability to poverty among oil palm smallholders in Indonesia." The Journal of Development Studies 52 (5): 681-695.

Castaldo, Adriana, Priya Deshingkar, and Andy McKay. 2012. "Internal migration, remittances and poverty: Evidence from Ghana and India." University of Sussex, Migrating Out of Poverty Working Paper 7.

Chaudhuri, Shubham. 2000. "Empirical models for assessing household vulnerability to poverty". Technical report, mimeo, Columbia University.

Chaudhuri, Shubham, Jyotsna Jalan, and Asep Suryahadi. 2002. "Assessing household vulnerability to poverty from cross-sectional data: A methodology and estimates from Indonesia". Columbia University, Department of Economics Discussion Paper N.010252 . 
De Weerdt, Joachim, Kathleen Beegle, Helene B. Lilleør, Stefan Dercon, Kalle Hirvonen, Martina Kirchberger, and Sonya Krutikova. 2012. Kagera Health and Development Survey 2010: Basic Information Document.

De Weerdt, Joachim and Kalle Hirvonen. 2016. "Risk sharing and internal migration". Economic Development and Cultural Change 65 (1): 63-86.

Dixit, Avinash K. and Robert S. Pindyck. 1994. Investment under uncertainty, Princeton University Press.

Esquivel, Gerardo and Alejandra Huerta-Pineda. 2007. "Remittances and poverty in Mexico: a propensity score matching approach". Integration and Trade Journal 27 (11): 45-57.

Foster, James, Joel Greer, and Erik Thorbecke. 1984. "A class of decomposable poverty measures". Econometrica 52 (3): 761-766.

Feeny, Simon and Lachlan McDonald. 2016. "Vulnerability to Multidimensional Poverty: Findings from Households in Melanesia." The Journal of Development Studies 52 (3): 447-464.

Gallardo, Mauricio 2017. "Identifying vulnerability to poverty: a critical survey." Journal of Economic Surveys 32 (4): 1074-1105.

Gibson, John, David McKenzie, and Steven Stillman. 2011. "The impacts of international migration on remaining household members: omnibus results from a migration lottery program". Review of Economics and Statistics 93 (4): 1297-1318.

Gibson, John, David McKenzie, and Steven Stillman. 2013. "Accounting for selectivity and duration-dependent heterogeneity when estimating the impact of emigration on incomes and poverty in sending areas". Economic Development and Cultural Change 61 (2): $247-280$.

Goldman, Mara J. and Fernando Riosmena. 2013. "Adaptive capacity in Tanzanian Maasailand: Changing strategies to cope with drought in fragmented landscapes". Global Environmental Change 23 (3): 588-597.

Günther, Isabel and Kenneth Harttgen. 2009. "Estimating households vulnerability to idiosyncratic and covariate shocks: a novel method applied in Madagascar". World Development 37 (7): 1222-1234.

Harris, John R. and Michael P. Todaro. 1970. "Migration, unemployment and development: a two-sector analysis". The American Economic Review 60 (1): 126-142.

Hirvonen, Kalle and Helene B. Lilleør. 2015. "Going back home: internal return migration in rural Tanzania". World Development 70: 186-202.

Hoddinott, John and Agnes R. Quisumbing. 2003. "Methods for microeconomic risk and vulnerability assessment." Social Protection Discussion Paper Series No. 0324, World Bank. 
Iacus, Stefano M., Gary King, and Giuseppe Porro. 2011. "Causal inference without balance checking: Coarsened exact matching". Political Analysis 20: 1-24.

Ingelaere, Bert, Luc Christiaensen, Joachim De Weerdt, and Ravi Kanbur. 2018. "Migrants, towns, poverty and jobs." World Bank Policy Research Working Paper 8340 .

IDRC. 2010. Reducing vulnerability among pastoralists in northern Kenya.

Imai, Katsushi S. 2011. "Poverty, undernutrition and vulnerability in rural India: Role of rural public works and food for work programmes." International Review of Applied Economics 25 (6): 669-691.

Imai, Katsushi S., Raghav Gaiha, and Woojin Kang. 2011. "Vulnerability and poverty dynamics in Vietnam." Applied Economics 43 (25): 3603-3618.

Imai, Katsushi S., Raghav Gaiha, and Ganesh Thapa. 2015. "Does non-farm sector employment reduce rural poverty and vulnerability? Evidence from Vietnam and India." Journal of Asian Economics 36: 47-61.

Jha, Raghbendra and Tu Dang. 2010. "Vulnerability to poverty in Papua New Guinea in 1996." Asian Economic Journal 24 (3): 235-251.

Kahneman, Daniel and Amos Tversky, A. 1979. "Prospect theory: an analysis of decision under risk." Econometrica 47: 263-292.

Kahneman, Daniel and Amos Tversky. 1991. "Loss aversion in riskless choice: a reference-dependent model." The Quarterly Journal of Economics 106 (4): 1039-61.

Keyantash, John and John A. Dracup. 2002. "The quantification of drought: an evaluation of drought indices." Bulletin of the American Meteorological Society 83 (8): 1167-1180.

Khandker, Shahidur R. 2007. "Coping with flood: role of institutions in Bangladesh." Agricultural Economics 36 (2): 169-180.

Khwaja, Yasmeen. 2002. "Should I stay or should I go? Migration under uncertainty: a real options approach." Brunel University, Department of Economics, Discussion Paper No. 02-10.

Lévi-Strauss, Claude. 1969. Elementary structures of kinship, Boston, Beacon Press.

Lucas, Robert E.B. 1997. Internal migration in developing countries. Handbook of Population and Family Economics 1: 721-798.

Magrini, Emiliano and Mauro Vigani. 2016. "Technology adoption and the multiple dimensions of food security: the case of maize in Tanzania." Food Security 8 (4): 707726. 
McKay, Andy and Priya Deshingkar. 2014. "Internal remittances and poverty: further evidence from Africa and Asia". University of Sussex, Migrating Out Of Poverty Working Paper 12.

McKenzie, David. 2015. "Learning about migration through experiments". Migration: Economic Change, Social Challenge, 68-82.

McKenzie, David and Dean Yang. 2010. "Experimental approaches in migration studies". Handbook of Research Method in Migration.

Moretto, Michele and Sergio Vergalli 2008. "Migration dynamics". Journal of Economics 93 (3): 223-265.

Nguyen, Loc Duc, Katharina Raabe, and Ulrike Grote. 2015. "Rural-urban migration, household vulnerability, and welfare in Vietnam." World Development 71: 79-93.

Oded, Stark. 1991. The Migration of Labor. Oxford, Basil Blackwell.

Ray, Debraj. 1998. Development economics, Princeton University Press.

Rayhan, Israt and Ulrike Grote. 2007. "Coping with floods: Does rural-urban migration play any role for survival in rural Bangladesh." Journal of identity and migration studies. 1 (2): 82-98.

Ratha, Dilip, Sonia Plaza, and Caglar Ozden. 2016. Migration and development: a role for the World Bank group, World Bank Publication.

Rosenzweig, Mark R. and Oded Stark. 1989. "Consumption smoothing, migration, and marriage: Evidence from rural India". The Journal of Political Economy 97 (4): 905926.

Schwartz, Aba. 1973. "Interpreting the effect of distance on migration." Journal of Political Economy 81 (5): 1153-1169.

Skoufias, Emmanuel and Agnes R. Quisumbing. 2003. "Consumption insurance and vulnerability to poverty: a synthesis of the evidence from Bangladesh, Ethiopia, Mali, Mexico, and Russia." IFPRI, FCND Discussion Paper No. 155.

Smith, Jeffrey A. and Petra E. Todd. 2005. "Does matching overcome Lalonde's critique of nonexperimental estimators?" Journal of Econometrics 125 (1): 305-353.

Stark, Oded and David Bloom. 1985. "The new economics of labor migration". The American Economic Review 75 (2): 173-178.

Stark, Oded and David Levhari. 1982. "On migration and risk in LDCs". Economic Development and Cultural Change 31 (1): 191-196.

Swain, Ranjula B. 2012. "Differential impact of microfinance delivery mechanism on vulnerability." Applied Economics Letters 19 (8): 721-724. 
Swain, Ranjula B. and Maria Floro. 2012. "Assessing the effect of microfinance on vulnerability and poverty among low income households." The Journal of Development Studies 48 (5): 605-618.

URT. 2012. National Sample Census Of Agriculture 2007/2008: Regional ReportKagera Region, Vol. V, The United Republic of Tanzania.

Vargas-Lundius, Rosemary. 2018. Syntesis Report - Internal Migration and Urbanization. Conference, organised by the World Bank's KNOMAD Thematic Working Group on Internal Migration and Urbanization in collaboration with Refugee and Migratory Movements Research Unit of University of Dhaka, and held in Dhaka, Bangladesh on April 30 - May 1, 2014.

Vergalli, Sergio. 2011. "Entry and exit strategies in migration dynamics". Journal of Labor Research 32 (4): 362-389.

Zereyesus, Yacob A., Weldensie T. Embaye, Francis Tsiboe, and Vincent AmanorBoadu. 2017. "Implications of Non-Farm Work to Vulnerability to Food PovertyRecent Evidence From Northern Ghana." World Development 91: 113-124.

WB. 2005. Afghanistan. Poverty, Vulnerability and Social Protection: An Initial Assessment, Human Development Unit, South Asia Region, Report No. 29694- AF, Washington DC.

WFP 2013. Comprehensive Food Security and Vulnerability Analysis: Tanzania, 2012. World Food Programme report. 


\section{Tables and figures}

Figure 1 Map of rainfall regimes in Tanzania.

Source: authors' elaboration using Stata 15

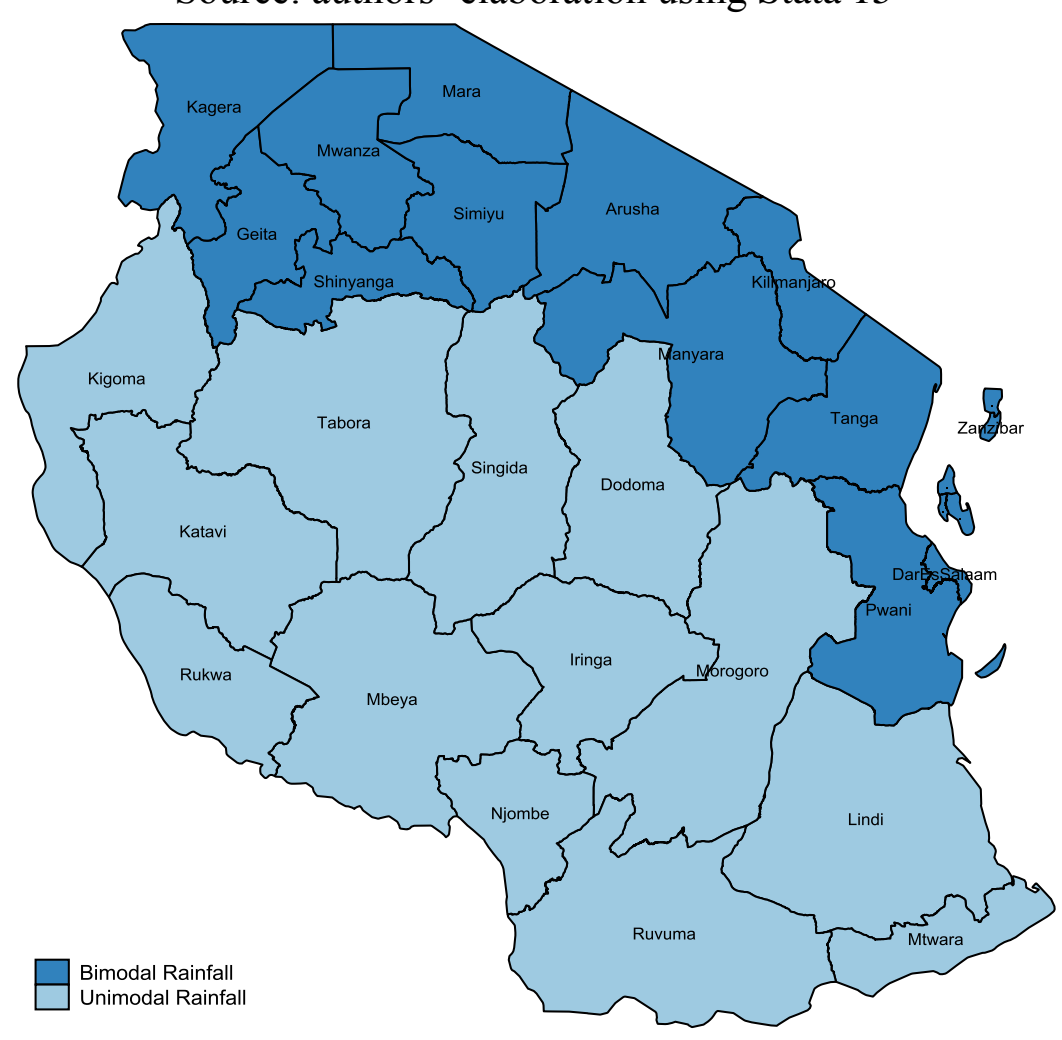


Figure 2 Rainfall anomaly by rainfall regime: average long-term difference of $\mathrm{mm}$ of rain for regions under bimodal and unimodal regime.

Source: authors' elaboration using FAO-GIEWS data

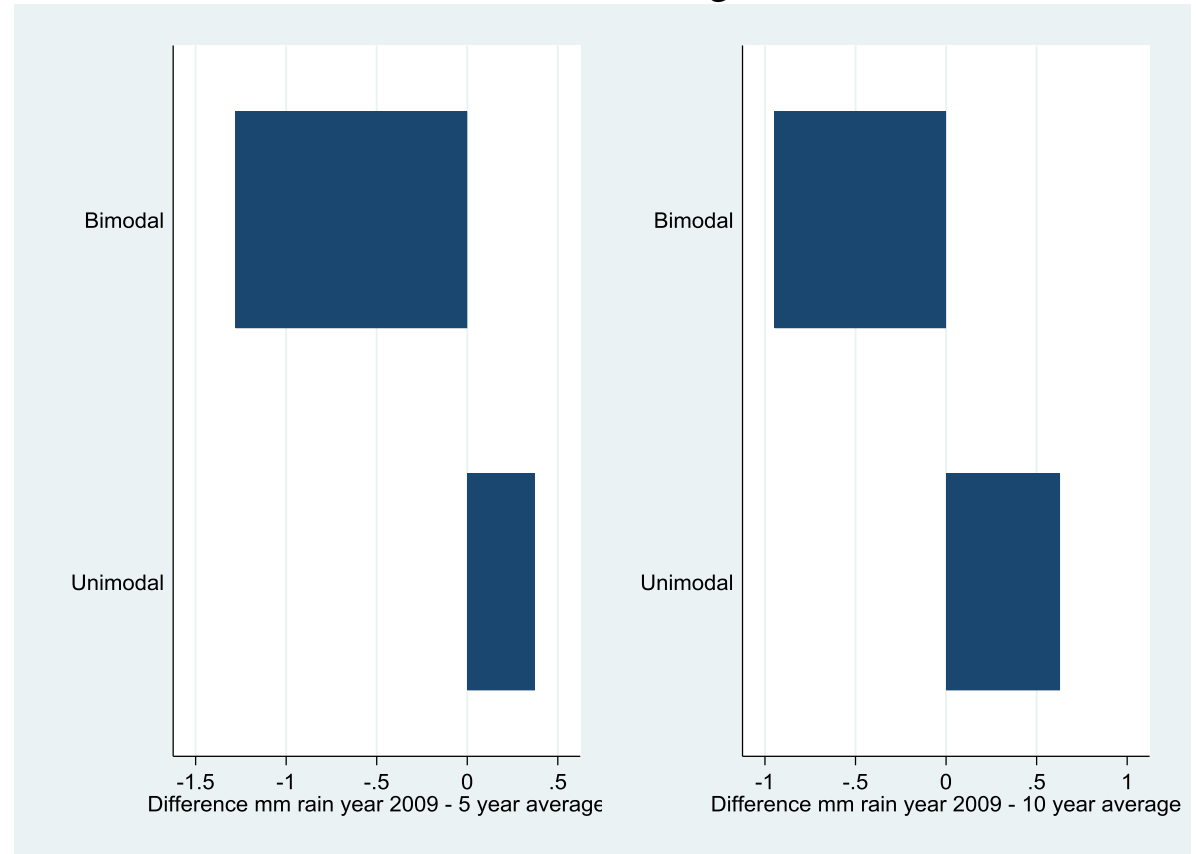


Table 1 Vulnerability to basic needs and food poverty at 2010

\begin{tabular}{|c|c|c|c|}
\hline & HHs with migrants & HHs without migrants & t-test (a) \\
\hline \multicolumn{4}{|l|}{ Basic needs } \\
\hline Poverty rate & 0.380 & 0.380 & \\
\hline Poverty line & 12.600 & 12.600 & \\
\hline \multirow[t]{2}{*}{ Vulnerability mean } & 0.410 & 0.430 & 0.170 \\
\hline & $(0.401)$ & $(0.384)$ & \\
\hline \multirow[t]{2}{*}{ (estimated) Mean (b) } & 13.170 & 13.040 & \\
\hline & $(4.288)$ & $(3.731)$ & \\
\hline \multirow[t]{2}{*}{ (estimated) Variance (c) } & 1.010 & 1.010 & \\
\hline & $(0.307)$ & $(0.198)$ & \\
\hline Vulnerability rate & 0.470 & 0.530 & \\
\hline \multicolumn{4}{|l|}{ Food } \\
\hline Poverty rate & 0.180 & 0.180 & \\
\hline Poverty line & 11.900 & 11.900 & \\
\hline \multirow[t]{2}{*}{ Vulnerability mean } & 0.340 & 0.360 & 0.240 \\
\hline & $(0.415)$ & $(0.385)$ & \\
\hline \multirow[t]{2}{*}{ (estimated) Mean (b) } & 13.200 & 12.960 & \\
\hline & $(6.738)$ & $(12.345)$ & \\
\hline \multirow[t]{2}{*}{ (estimated) Variance (c) } & 1.020 & 0.990 & \\
\hline & $(0.360)$ & $(0.270)$ & \\
\hline Vulnerability rate & 0.480 & 0.520 & \\
\hline Observations & 325 & 910 & \\
\hline \multicolumn{4}{|c|}{$\begin{array}{l}\text { (a) p-value of the t-test of equality of vulnerability rates between households with and without migrants. } \\
\text { Standard deviation in parenthesis. } \\
\text { (b)The estimates of the mean of log consumption - represented by } X_{i} \hat{\beta} \text { in the VEP formula (1) - are obtained } \\
\text { from a three-step feasible generalised least squares procedure. }\end{array}$} \\
\hline
\end{tabular}


Table 2 Vulnerability variation (2010-2004) by categories of households

\begin{tabular}{|c|c|c|c|c|}
\hline & \multicolumn{2}{|c|}{ Basic needs } & \multicolumn{2}{|r|}{ Food } \\
\hline & Extended HHs & HHs with same head & Extended HHs & HHs with same head \\
\hline \multirow[t]{2}{*}{ With migrants } & -0.094 & -0.060 & -0.002 & -0.103 \\
\hline & $(0.527)$ & $(0.615)$ & $(0.587)$ & $(0.489)$ \\
\hline \multirow[t]{2}{*}{ Without migrants } & -0.015 & 0.001 & 0.033 & 0.048 \\
\hline & $(0.501)$ & $(0.525)$ & $(0.507)$ & $(0.411)$ \\
\hline t-test (a) & 0.025 & 0.431 & 0.368 & 0.000 \\
\hline Observations & 1,235 & 881 & 1,235 & 881 \\
\hline $\begin{array}{l}\text { Note: } \\
\text { (a) p-value of the t } \\
\text { Standard deviatior } \\
\text { Source: Kagera He }\end{array}$ & $\begin{array}{l}\text { tof equality of } \mathrm{vl} \\
\text { parenthesis. } \\
\text { and Developme }\end{array}$ & rability variation bety & $\begin{array}{l}\text { households with } \\
\text { III (2010). }\end{array}$ & without migrants. \\
\hline
\end{tabular}


Table 3 The effect of migration (ATT) on VEP variation (2010-2004)

\begin{tabular}{|c|c|c|c|c|}
\hline & \multicolumn{2}{|c|}{ Extended HHs } & \multicolumn{2}{|c|}{ HHs with same head } \\
\hline & (a) & (b) & (c) & (d) \\
\hline & Basic needs & Food & Basic needs & Food \\
\hline \multicolumn{5}{|c|}{ Propensity score matching } \\
\hline \multirow[t]{2}{*}{ Nearest-neighbour } & $-0.153 * *$ & -0.062 & -0.014 & $-0.155^{* *}$ \\
\hline & $(0.062)$ & $(0.066)$ & $(0.051)$ & $(0.061)$ \\
\hline \multirow[t]{2}{*}{ Caliper } & $-0.153 * *$ & -0.062 & -0.014 & $-0.155^{* *}$ \\
\hline & $(0.062)$ & $(0.066)$ & $(0.051)$ & $(0.061)$ \\
\hline \multirow[t]{2}{*}{ Kernel } & $-0.088 * *$ & -0.024 & $-0.062^{*}$ & $-0.154 * * *$ \\
\hline & $(0.035)$ & $(0.036)$ & $(0.037)$ & $(0.038)$ \\
\hline \multicolumn{5}{|c|}{ Matching on multiple variables } \\
\hline \multirow{2}{*}{ Mahalanobis distance } & $-0.106 * *$ & -0.035 & -0.013 & $-0.119 * *$ \\
\hline & $(0.047)$ & $(0.054)$ & $(0.051)$ & $(0.057)$ \\
\hline \multirow[t]{2}{*}{ Euclidean distance } & -0.056 & -0.025 & -0.019 & $-0.168 * * *$ \\
\hline & $(0.045)$ & $(0.056)$ & $(0.054)$ & $(0.060)$ \\
\hline \multirow[t]{2}{*}{ Ivariance distance } & $-0.102 * *$ & -0.065 & -0.012 & $-0.150^{* *}$ \\
\hline & $(0.048)$ & $(0.059)$ & $(0.055)$ & $(0.060)$ \\
\hline \multicolumn{5}{|c|}{ Coarsened exact matching } \\
\hline & -0.075 & -0.029 & $-0.070 * *$ & $-0.262 * * *$ \\
\hline & $(0.073)$ & $(0.059)$ & $(0.030)$ & $(0.057)$ \\
\hline Observations & 1,325 & 1,325 & 881 & 881 \\
\hline Treated & 325 & 325 & 195 & 195 \\
\hline Control & 910 & 910 & 686 & 686 \\
\hline \multicolumn{5}{|c|}{ Standard errors in parentheses. $* * * \mathrm{p}<0.01, * * \mathrm{p}<0.05,{ }^{*} \mathrm{p}<0.1$} \\
\hline \multicolumn{5}{|c|}{$\begin{array}{l}\text { Note: } \\
\text { Matching and bias-adjustment variables: household size; number of males; number of members with primary education } \\
\text { number of members with secondary education, a dummy for whether the origin household is living in Bukoba urban } \\
\text { number of cattle owned by the household; number of sheep owned by the household; acre of plots owned by th } \\
\text { household; dummy for having a bank account, dummy for having experienced a shock; dummy for participating i } \\
\text { informal organizations. } \\
\text { Source: Kagera Health and Development Survey, wave II (2004) and III (2010). }\end{array}$} \\
\hline
\end{tabular}


Table 4 Impact of migrant location on VEP variation of origin households

\begin{tabular}{lcc}
\hline & \multicolumn{2}{c}{ VEP variation } \\
\hline & Basic needs & Food \\
\hline Distance & 0.000 & 0.000 \\
& $(0.000)$ & $(0.000)$ \\
Unimodal & $-0.419^{*}$ & $-0.551^{* *}$ \\
Distance * Unimodal & $(0.250)$ & $(0.222)$ \\
& 0.000 & $0.001^{* *}$ \\
Diff Number of cattle & $(0.000)$ & $(0.000)$ \\
& -0.002 & -0.002 \\
Diff Acre of owned plots & $(0.003)$ & $(0.002)$ \\
& $-0.012^{*}$ & $0.014^{* *}$ \\
Diff Number of enterprises & $(0.006)$ & $(0.006)$ \\
Diff Toilet & -0.030 & $0.096^{* * *}$ \\
Diff Electricity & $(0.0404)$ & $(0.0359)$ \\
Constant & -0.218 & $-0.317^{* *}$ \\
Observations & $(0.144)$ & $(0.128)$ \\
R-squared & $0.516^{* *}$ & 0.231 \\
Standard errors in parentheses $* * * \mathrm{p}<0.01, * * \mathrm{p}<0.05, * \mathrm{p}<0.1$ & $(0.202)$ \\
Souce Kag & $(0.227)$ & $-0.162^{* * *}$ \\
& $-0.117^{* * *}$ & $(0.040)$ \\
& $(0.045)$ & 325 \\
& 325 & 0.113 \\
\hline
\end{tabular}

Source: Kagera Health and Development Survey, wave II (2004) and III (2010). 


\section{Appendix}

Table A1 Summary statistics by wave and household type: mean values and standard deviation (in parentheses)

\begin{tabular}{|c|c|c|c|c|c|}
\hline \multirow[b]{3}{*}{ Variable } & \multirow{3}{*}{$\begin{array}{c}\text { KHDS II (2004) } \\
\text { Total sample }\end{array}$} & \multicolumn{4}{|c|}{ KHDS III (2010) } \\
\hline & & \multicolumn{2}{|c|}{ Extended $\mathrm{HH}$} & \multicolumn{2}{|c|}{ Same HH head } \\
\hline & & Without migrants & With migrants & Without migrants & With migrants \\
\hline \multirow[t]{2}{*}{ Age (HH head) } & 46.230 & 45.311 & 50.490 & 47.966 & 59.254 \\
\hline & $(17.320)$ & $(17.097)$ & $(18.569)$ & $(16.533)$ & $(15.065)$ \\
\hline \multirow[t]{2}{*}{ Sq. Age (HH head) } & 2547.992 & 2345.042 & 2892.948 & 2573.654 & 3736.757 \\
\hline & (1822.134) & $(1827.886)$ & (1995.895) & $(1833.051)$ & (1843.949) \\
\hline \multirow[t]{2}{*}{ Male (HH head) } & 0.750 & 0.782 & 0.663 & 0.815 & 0.638 \\
\hline & $(0.430)$ & $(0.413)$ & $(0.473)$ & $(0.389)$ & $(0.482)$ \\
\hline \multirow[t]{2}{*}{ Married (HH head) } & 0.690 & 0.712 & 0.618 & 0.742 & 0.638 \\
\hline & $(0.460)$ & $(0.453)$ & $(0.487)$ & $(0.438)$ & $(0.482)$ \\
\hline \multirow[t]{2}{*}{ Employee (HH head) } & 0.340 & 0.403 & 0.284 & 0.383 & 0.184 \\
\hline & $(0.480)$ & $(0.491)$ & $(0.452)$ & $(0.487)$ & $(0.388)$ \\
\hline \multirow[t]{2}{*}{ Farmer own field (HH head) } & 0.900 & 0.893 & 0.908 & 0.890 & 0.924 \\
\hline & $(0.300)$ & $(0.310)$ & $(0.289)$ & $(0.313)$ & $(0.265)$ \\
\hline \multirow[t]{2}{*}{ Farmer not own field (HH head) } & 0.340 & 0.414 & 0.441 & 0.401 & 0.411 \\
\hline & $(0.480)$ & $(0.493)$ & $(0.497)$ & $(0.491)$ & $(0.493)$ \\
\hline \multirow[t]{2}{*}{ HH size } & 5.320 & 4.806 & 4.657 & 5.153 & 5.200 \\
\hline & $(2.610)$ & $(2.239)$ & $(2.449)$ & $(2.280)$ & $(2.686)$ \\
\hline \multirow[t]{2}{*}{ N. children $(<6$ years $)$} & 1.060 & 1.028 & 0.797 & 1.053 & 0.649 \\
\hline & $(1.020)$ & $(1.009)$ & $(0.974)$ & $(1.034)$ & $(0.879)$ \\
\hline \multirow[t]{2}{*}{ N. adults (> 18years) } & 2.480 & 1.662 & 1.552 & 1.901 & 2.022 \\
\hline & $(1.170)$ & $(1.482)$ & $(1.561)$ & $(1.480)$ & $(1.658)$ \\
\hline \multirow[t]{2}{*}{ Number of educated members (a) } & 2.900 & 2.990 & 3.200 & 3.154 & 3.820 \\
\hline & $(1.810)$ & $(1.741)$ & $(1.792)$ & $(1.767)$ & $(1.916)$ \\
\hline \multirow[t]{2}{*}{$\begin{array}{l}\text { Number of members with primary } \\
\text { education }\end{array}$} & 2.703 & 2.926 & 3.065 & 3.138 & 3.597 \\
\hline & $(1.879)$ & $(1.763)$ & $(1.932)$ & $(1.768)$ & $(2.123)$ \\
\hline \multirow[t]{2}{*}{$\begin{array}{l}\text { Number of members with } \\
\text { secondary education }\end{array}$} & 0.200 & 0.301 & 0.440 & 0.313 & 0.500 \\
\hline & $(0.579)$ & $(0.698)$ & $(0.849)$ & $(0.724)$ & $(0.879)$ \\
\hline \multirow[t]{2}{*}{ Number of employees } & 0.710 & 0.666 & 0.549 & 0.665 & 0.497 \\
\hline & $(0.870)$ & $(0.769)$ & $(0.737)$ & $(0.790)$ & $(0.738)$ \\
\hline \multirow[t]{2}{*}{ Number of farmers in $\mathrm{HH}$ field } & 3.260 & 2.912 & 3.209 & 3.119 & 3.741 \\
\hline & $(1.940)$ & $(1.653)$ & $(1.882)$ & $(1.718)$ & $(1.899)$ \\
\hline \multirow[t]{2}{*}{ Number of farmers not in $\mathrm{HH}$ field } & 0.640 & 0.712 & 0.748 & 0.711 & 0.773 \\
\hline & $(0.800)$ & $(0.803)$ & $(0.833)$ & $(0.811)$ & $(0.829)$ \\
\hline \multirow[t]{2}{*}{ Acre of owned plots (b) } & 3.370 & 2.789 & 3.414 & 3.052 & 4.462 \\
\hline & $(3.930)$ & $(2.754)$ & $(4.465)$ & $(2.942)$ & $(5.395)$ \\
\hline Number of cattle (c) & 6.530 & 0.617 & 0.912 & 0.737 & 1.562 \\
\hline
\end{tabular}




\begin{tabular}{|c|c|c|c|c|c|}
\hline & $(10.890)$ & $(2.626)$ & $(4.346)$ & $(2.936)$ & $(5.937)$ \\
\hline \multirow[t]{2}{*}{ Number of sheep (d) } & 1.981 & 1.476 & 1.788 & 1.644 & 2.347 \\
\hline & $(5.871)$ & $(2.965)$ & $(4.120)$ & $(3.221)$ & $(5.064)$ \\
\hline \multirow[t]{2}{*}{ Number of owned enterprises (e) } & 0.600 & 0.713 & 0.788 & 0.706 & 0.811 \\
\hline & $(0.700)$ & $(0.812)$ & $(0.929)$ & $(0.818)$ & $(0.922)$ \\
\hline \multirow[t]{2}{*}{ Toilet (f) } & 0.930 & 0.946 & 0.951 & 0.955 & 0.957 \\
\hline & $(0.250)$ & $(0.225)$ & $(0.216)$ & $(0.206)$ & $(0.204)$ \\
\hline \multirow[t]{2}{*}{ Electricity (g) } & 0.050 & 0.056 & 0.056 & 0.049 & 0.054 \\
\hline & $(0.220)$ & $(0.230)$ & $(0.229)$ & $(0.216)$ & $(0.227)$ \\
\hline \multirow[t]{2}{*}{$\begin{array}{l}\text { Ownership of a bank account } \\
\text { (dummy) }\end{array}$} & 0.095 & 0.128 & 0.124 & 0.132 & 0.168 \\
\hline & $(0.293)$ & $(0.334)$ & $(0.330)$ & $(0.339)$ & $(0.374)$ \\
\hline \multirow[t]{2}{*}{$\begin{array}{l}\text { Participation in informal } \\
\text { organizations (dummy) (h) }\end{array}$} & 0.693 & $\mathrm{n} / \mathrm{a}$ & $\mathrm{n} / \mathrm{a}$ & $\mathrm{n} / \mathrm{a}$ & $\mathrm{n} / \mathrm{a}$ \\
\hline & $(0.461)$ & & & & \\
\hline \multirow[t]{2}{*}{ Shock (dummy) (i) } & 0.124 & 0.012 & 0.007 & 0.012 & 0.006 \\
\hline & $(0.330)$ & $(0.106)$ & $(0.084)$ & $(0.107)$ & $(0.077)$ \\
\hline \multirow[t]{2}{*}{ Karagwe } & 0.140 & 0.146 & 0.124 & 0.147 & 0.130 \\
\hline & $(0.340)$ & $(0.353)$ & $(0.330)$ & $(0.354)$ & $(0.337)$ \\
\hline \multirow[t]{2}{*}{ Bukoba rural } & 0.334 & 0.320 & 0.356 & 0.331 & 0.351 \\
\hline & $(0.471)$ & $(0.467)$ & $(0.480)$ & $(0.471)$ & $(0.479)$ \\
\hline \multirow[t]{2}{*}{ Muleba } & 0.150 & 0.137 & 0.199 & 0.128 & 0.232 \\
\hline & $(0.360)$ & $(0.344)$ & $(0.400)$ & $(0.334)$ & $(0.424)$ \\
\hline \multirow[t]{2}{*}{ Biharamulo } & 0.060 & 0.073 & 0.085 & 0.071 & 0.059 \\
\hline & $(0.240)$ & $(0.260)$ & $(0.279)$ & $(0.257)$ & $(0.237)$ \\
\hline \multirow[t]{2}{*}{ Ngara } & 0.130 & 0.144 & 0.072 & 0.147 & 0.086 \\
\hline & $(0.340)$ & $(0.351)$ & $(0.259)$ & $(0.354)$ & $(0.282)$ \\
\hline \multirow[t]{2}{*}{ Bukoba urban } & 0.171 & 0.181 & 0.163 & 0.177 & 0.141 \\
\hline & $(0.376)$ & $(0.385)$ & $(0.370)$ & $(0.382)$ & $(0.348)$ \\
\hline \multirow[t]{2}{*}{ Total cons. pc (in TSh) } & 392,444 & 477,113 & 505,627 & 464,439 & 495,579 \\
\hline & $(249,268)$ & $(365,293)$ & $(360,985)$ & $(349,791)$ & $(347,482)$ \\
\hline \multirow[t]{2}{*}{ Food cons. pc (in TSh) } & 275,699 & 303,920 & 310,092 & 297,579 & 302,676 \\
\hline & $(179,095)$ & $(232,828)$ & $(193,605)$ & $(213,831)$ & $(159,426)$ \\
\hline \multirow[t]{2}{*}{ Vulnerability to basic needs } & 0.407 & 0.381 & 0.396 & 0.362 & 0.458 \\
\hline & $(0.344)$ & $(0.383)$ & $(0.390)$ & $(0.357)$ & $(0.393)$ \\
\hline \multirow[t]{2}{*}{ Vulnerability to food poverty } & 0.310 & 0.326 & 0.347 & 0.319 & 0.370 \\
\hline & $(0.259)$ & $(0.293)$ & $(0.319)$ & $(0.245)$ & $(0.318)$ \\
\hline Obs. & 1,083 & 910 & 325 & 686 & 195 \\
\hline
\end{tabular}

Note:

(a) Number of household members with a primary (from 1 to 8 years of schooling) or secondary education (from 9 to 19 years). (b) Acre of total plots owned by the household: they include cultivated, rented out or left fallow plots. (c) Number of total cattle, of all ages, owned by the household at the time of the interview. (d) Number of total sheep of all ages, owned by the household at the time of the interview. (e) Number of all non-farm enterprises owned by household members. They include, for example, selling fruits, car washing, driving car, hair dressing, bicycle transportation and mechanics etc. (f) Dummy equal to one if the household uses a flush toilet and zero otherwise. (g) Dummy equal to one is the main source of lighting for the household dwelling is electricity. (h) Information available only in the KHDS II. (i) Dummy equal to one is the household experienced any type of shock in the 12 months preceding the interview.

Source: Kagera Health and Development Survey, wave II (2004) and III (2010). 
Table A2 Consumption models using FGLS procedure

\begin{tabular}{|c|c|c|c|c|}
\hline & \multicolumn{2}{|c|}{2004} & \multicolumn{2}{|c|}{2010} \\
\hline & $\begin{array}{c}\text { Total } \\
\text { consumption }\end{array}$ & $\begin{array}{c}\text { Food } \\
\text { consumption }\end{array}$ & $\begin{array}{c}\text { Total } \\
\text { consumption }\end{array}$ & $\begin{array}{c}\text { Food } \\
\text { consumption }\end{array}$ \\
\hline \multirow[t]{2}{*}{ Age (HH head) } & 0.005 & $0.009 *$ & -0.0009 & 0.004 \\
\hline & $(0.005)$ & $(0.006)$ & $(0.005)$ & $(0.005)$ \\
\hline \multirow[t]{2}{*}{ Squared age (HH head) } & -0.0001 & $-0.0001 * *$ & 0.000 & -0.0001 \\
\hline & 0.000 & $(0.000)$ & $(0.000)$ & $(0.000)$ \\
\hline \multirow[t]{2}{*}{ Male (HH head) } & $0.173^{* * *} *$ & $0.181 * * *$ & $0.212^{* * * *}$ & $0.365 * * *$ \\
\hline & $(0.053)$ & $(0.060)$ & $(0.052)$ & $(0.055)$ \\
\hline \multirow[t]{2}{*}{ Married (HH head) } & -0.053 & -0.055 & $-0.133 * * *$ & $-0.172 * * *$ \\
\hline & $(0.053)$ & $(0.060)$ & $(0.050)$ & $(0.054)$ \\
\hline \multirow[t]{2}{*}{ Employee (HH head) } & 0.067 & 0.043 & 0.030 & 0.019 \\
\hline & $(0.042)$ & $(0.050)$ & $(0.036)$ & $(0.041)$ \\
\hline \multirow[t]{2}{*}{ Farmer in own field (HH head) } & $-0.110 * * *$ & $-0.114^{* *}$ & $-0.265^{* * *}$ & $-0.276^{* * *}$ \\
\hline & $(0.040)$ & $(0.046)$ & $(0.040)$ & $(0.044)$ \\
\hline \multirow[t]{2}{*}{$\begin{array}{l}\text { Farmer not in own field }(\mathrm{HH} \\
\text { head) }\end{array}$} & $0.095 * *$ & $0.119^{* *}$ & $0.099 * * *$ & $0.111 * * *$ \\
\hline & $(0.041)$ & $(0.049)$ & $(0.036)$ & $(0.041)$ \\
\hline \multirow[t]{2}{*}{$\mathrm{HH}$ size } & $-0.176^{* * * *}$ & $-0.119 * * *$ & $-0.218 * * *$ & $-0.169 * * *$ \\
\hline & $(0.019)$ & $(0.023)$ & $(0.020)$ & $(0.025)$ \\
\hline \multirow[t]{2}{*}{ Squared HH size } & $0.007 * * *$ & $0.005 * * *$ & $0.005 * * *$ & $0.005 * * *$ \\
\hline & $(0.001)$ & $(0.001)$ & $(0.001)$ & $(0.002)$ \\
\hline \multirow[t]{2}{*}{ Number of children (<6 years) } & $-0.052 * *$ & $-0.082 * * *$ & -0.018 & -0.019 \\
\hline & $(0.021)$ & $(0.025)$ & $(0.022)$ & $(0.025)$ \\
\hline \multirow[t]{2}{*}{ Number of adults (>18 years) } & $0.064 * * *$ & $0.065 * * *$ & $0.088 * * *$ & $0.055 * *$ \\
\hline & $(0.018)$ & $(0.022)$ & $(0.020)$ & $(0.022)$ \\
\hline \multirow[t]{2}{*}{ Number of educated members } & $0.054 * * *$ & $0.029 *$ & $0.114 * * *$ & $0.081 * * *$ \\
\hline & $(0.014)$ & $(0.017)$ & $(0.016)$ & $(0.018)$ \\
\hline \multirow[t]{2}{*}{ Number of employees } & -0.026 & -0.021 & $-0.038 *$ & -0.018 \\
\hline & $(0.023)$ & $(0.028)$ & $(0.022)$ & $(0.026)$ \\
\hline \multirow[t]{2}{*}{ Acre of own plots } & 0.003 & $0.014 * *$ & $0.021 * * *$ & $0.017 * * *$ \\
\hline & $(0.003)$ & $(0.006)$ & $(0.004)$ & $(0.006)$ \\
\hline \multirow[t]{2}{*}{ Number of cattle } & $0.009 * * *$ & $0.007 * * *$ & $0.004 * * *$ & 0.001 \\
\hline & $(0.001)$ & $(0.002)$ & $(0.001)$ & $(0.001)$ \\
\hline \multirow[t]{2}{*}{ Number of enterprises } & $0.064 * *$ & $0.064 * *$ & 0.009 & 0.012 \\
\hline & $(0.027)$ & $(0.032)$ & $(0.021)$ & $(0.025)$ \\
\hline \multirow[t]{2}{*}{ Toilet in dwelling } & $0.175^{* * *}$ & $0.107 *$ & 0.101 & 0.090 \\
\hline & $(0.053)$ & $(0.061)$ & $(0.062)$ & $(0.078)$ \\
\hline \multirow[t]{2}{*}{ Electricity } & $0.374 * * *$ & $0.333 * * *$ & $0.578 * * *$ & $0.467 * * *$ \\
\hline & $(0.061)$ & $(0.074)$ & $(0.060)$ & $(0.066)$ \\
\hline \multirow[t]{2}{*}{ Karagwe } & $0.395 * * *$ & $0.389 * * *$ & $0.295^{* * *} *$ & $0.145^{* *}$ \\
\hline & $(0.051)$ & $(0.064)$ & $(0.051)$ & $(0.059)$ \\
\hline \multirow[t]{2}{*}{ Bukoba } & $0.349 * * *$ & $0.357 * * *$ & 0.062 & 0.019 \\
\hline & $(0.042)$ & $(0.050)$ & $(0.045)$ & $(0.048)$ \\
\hline Muleba & $0.320 * * *$ & $0.279 * * *$ & 0.032 & -0.044 \\
\hline & $(0.051)$ & $(0.059)$ & $(0.052)$ & $(0.056)$ \\
\hline Biharamulo & $-0.164 * * *$ & $-0.209 * * *$ & $-0.141^{* *}$ & $-0.169 * * *$ \\
\hline & $(0.060)$ & $(0.072)$ & $(0.063)$ & $(0.065)$ \\
\hline Constant & $12.493 * * *$ & $11.938 * * *$ & $13.265^{* * *}$ & $12.586^{* * *}$ \\
\hline & $(0.142)$ & $(0.164)$ & $(0.145)$ & $(0.162)$ \\
\hline Observations & 1,083 & 1,083 & 1,235 & 1,235 \\
\hline R-squared & 0.999 & 0.998 & 0.999 & 0.998 \\
\hline
\end{tabular}

Standard errors in parentheses. $* * * \mathrm{p}<0.01, * * \mathrm{p}<0.05, * \mathrm{p}<0.1$

Source: Kagera Health and Development Survey, wave II (2004) and III (2010). 
Table A3 Probit and Logit models of having migrants on 2004 household characteristics by typology of households (extended HHs or HHs with same head)

\begin{tabular}{|c|c|c|c|c|}
\hline & \multicolumn{2}{|c|}{ Extended HHs } & \multicolumn{2}{|c|}{ HHs with same head } \\
\hline & (1) & (2) & (3) & (4) \\
\hline & Probit & Logit & Probit & Logit \\
\hline \multirow[t]{2}{*}{ HH size } & $0.111 * * *$ & $0.186^{* * * *}$ & $0.114 * * *$ & $0.190 * * *$ \\
\hline & $(0.031)$ & $(0.053)$ & $(0.039)$ & $(0.068)$ \\
\hline \multirow[t]{2}{*}{ N. males } & $-0.107 * * *$ & $-0.180 * *$ & $-0.150 * * *$ & $-0.258 * * *$ \\
\hline & $(0.041)$ & $(0.071)$ & $(0.053)$ & $(0.092)$ \\
\hline \multirow[t]{2}{*}{ N. members with primary education } & $0.240 * * *$ & $0.408^{* * *}$ & $0.255^{* * *}$ & $0.446^{* * *}$ \\
\hline & $(0.037)$ & $(0.065)$ & $(0.048)$ & $(0.086)$ \\
\hline \multirow[t]{2}{*}{ N. members with secondary education } & $0.441 * * *$ & $0.766^{* * * *}$ & $0.443 * * *$ & $0.777 * * *$ \\
\hline & $(0.088)$ & $(0.159)$ & $(0.111)$ & $(0.205)$ \\
\hline \multirow[t]{2}{*}{ Acre of plots } & 0.001 & -0.000 & 0.0161 & 0.0256 \\
\hline & $(0.012)$ & $(0.021)$ & $(0.016)$ & $(0.028)$ \\
\hline \multirow[t]{2}{*}{ Cattle } & 0.022 & 0.038 & 0.017 & 0.032 \\
\hline & $(0.014)$ & $(0.023)$ & $(0.018)$ & $(0.029)$ \\
\hline \multirow[t]{2}{*}{ Sheep } & 0.002 & 0.005 & -0.001 & -0.002 \\
\hline & $(0.009)$ & $(0.017)$ & $(0.008)$ & $(0.013)$ \\
\hline \multirow[t]{2}{*}{ Bukoba urban } & $-0.214^{*}$ & -0.364 & -0.254 & $-0.464 *$ \\
\hline & $(0.128)$ & $(0.224)$ & $(0.156)$ & $(0.280)$ \\
\hline \multirow[t]{2}{*}{ Informal organizations } & 0.045 & 0.096 & 0.130 & 0.246 \\
\hline & $(0.102)$ & $(0.178)$ & $(0.124)$ & $(0.224)$ \\
\hline \multirow[t]{2}{*}{ Bank account } & $-0.498 * * *$ & $-0.925 * * *$ & $-0.522 * *$ & $-0.981 * *$ \\
\hline & $(0.176)$ & $(0.323)$ & $(0.228)$ & $(0.431)$ \\
\hline \multirow[t]{2}{*}{ Shock at 2003} & 0.172 & 0.280 & $0.244 *$ & 0.396 \\
\hline & $(0.124)$ & $(0.213)$ & $(0.147)$ & $(0.259)$ \\
\hline \multirow[t]{2}{*}{ Constant } & $-1.757 * * *$ & $-2.949 * * *$ & $-1.884 * * *$ & $-3.185^{* * * *}$ \\
\hline & $(0.135)$ & $(0.244)$ & $(0.162)$ & $(0.298)$ \\
\hline Prob> chi 2 & 0.000 & 0.000 & 0.000 & 0.000 \\
\hline Pseudo R2 & 0.156 & 0.154 & 0.158 & 0.156 \\
\hline Log likelihood & -604.015 & -605.078 & -391.804 & -392.685 \\
\hline Observations & 1,235 & 1,235 & 881 & 881 \\
\hline
\end{tabular}


Table A4 Balanced test: variables used for matching households

\begin{tabular}{|c|c|c|c|c|c|c|c|}
\hline Variable & $\begin{array}{l}\text { Matched/ } \\
\text { Unmatched }\end{array}$ & Mean treated & Mean Control & Bias & Reduction & $\mathrm{t}$ & p-value \\
\hline \multicolumn{8}{|c|}{ Extended households $(1,325)$} \\
\hline \multirow[t]{2}{*}{ HH size } & $\mathrm{U}$ & 6.755 & 4.728 & 79.8 & & 12.59 & 0.000 \\
\hline & M & 6.656 & 6.756 & -3.9 & 95.1 & -0.45 & 0.651 \\
\hline \multirow[t]{2}{*}{ Acre of owned land } & $\mathrm{U}$ & 4.370 & 3.127 & 29.3 & & 4.82 & 0.000 \\
\hline & M & 4.303 & 4.107 & 4.6 & 84.3 & 0.50 & 0.614 \\
\hline \multirow[t]{2}{*}{ Number of cattle } & $\mathrm{U}$ & 1.035 & 0.436 & 16.6 & & 2.90 & 0.004 \\
\hline & M & 0.997 & 0.820 & 4.9 & 70.4 & 0.54 & 0.587 \\
\hline \multirow[t]{2}{*}{ Living in Bukoba urban } & $\mathrm{U}$ & 0.152 & 0.172 & -5.4 & & -0.78 & 0.433 \\
\hline & M & 0.153 & 0.150 & 0.7 & 86.9 & 0.09 & 0.931 \\
\hline \multirow[t]{2}{*}{ Participating in informal organizations } & $\mathrm{U}$ & 0.766 & 0.676 & 20.1 & & 2.88 & 0.004 \\
\hline & M & 0.767 & 0.743 & 5.5 & 72.7 & 0.68 & 0.495 \\
\hline \multirow[t]{2}{*}{ N. of males } & $\mathrm{U}$ & 3.166 & 2.361 & 49.2 & & 7.88 & 0.000 \\
\hline & M & 3.115 & 3.131 & -1.0 & 98.0 & -0.11 & 0.910 \\
\hline \multirow{2}{*}{$\begin{array}{l}\text { N. of members with primary } \\
\text { education }\end{array}$} & $\mathrm{U}$ & 3.717 & 2.211 & 87.1 & & 13.71 & 0.000 \\
\hline & M & 3.677 & 3.689 & -0.7 & 99.2 & -0.08 & 0.940 \\
\hline \multirow{2}{*}{$\begin{array}{l}\text { N. of members with primary } \\
\text { education }\end{array}$} & $\mathrm{U}$ & 0.359 & 0.122 & 37.2 & & 6.41 & 0.000 \\
\hline & M & 0.347 & 0.304 & 6.8 & 81.8 & 0.68 & 0.498 \\
\hline \multirow[t]{2}{*}{ N. of sheep } & $\mathrm{U}$ & 2.759 & 1.739 & 13.2 & & 2.47 & 0.014 \\
\hline & M & 2.674 & 2.064 & 7.9 & 40.2 & 0.94 & 0.347 \\
\hline \multirow[t]{2}{*}{ Having a bank account } & $\mathrm{U}$ & 0.100 & 0.085 & 5.3 & & 0.79 & 0.427 \\
\hline & M & 0.097 & 0.107 & -3.5 & 34.3 & -0.40 & 0.690 \\
\hline \multirow[t]{2}{*}{ Shock } & $\mathrm{U}$ & 0.148 & 0.131 & 4.9 & & 0.74 & 0.462 \\
\hline & M & 0.146 & 0.162 & -4.6 & 6.1 & -0.54 & 0.593 \\
\hline \multicolumn{8}{|c|}{ Households with same heads (881) } \\
\hline \multirow[t]{2}{*}{ HH size } & $\mathrm{U}$ & 6.506 & 4.546 & 76.0 & & 9.88 & 0.000 \\
\hline & M & 6.341 & 6.437 & -3.7 & 95.1 & -0.34 & 0.732 \\
\hline \multirow[t]{2}{*}{ Acre of owned land } & $\mathrm{U}$ & 4.505 & 2.844 & 36.2 & & 5.28 & 0.000 \\
\hline & M & 4.380 & 3.721 & 14.4 & 60.3 & 1.31 & 0.189 \\
\hline \multirow[t]{2}{*}{ Number of cattle } & $\mathrm{U}$ & 1.163 & 0.448 & 20.5 & & 2.87 & 0.004 \\
\hline & M & 1.108 & 0.904 & 5.9 & 71.4 & 0.49 & 0.623 \\
\hline \multirow[t]{2}{*}{ Living in Bukoba urban } & $\mathrm{U}$ & 0.129 & 0.172 & -11.8 & & -1.36 & 0.175 \\
\hline & M & 0.131 & 0.142 & -3.2 & 73.4 & -0.31 & 0.759 \\
\hline \multirow[t]{2}{*}{ Participating in informal organizations } & $\mathrm{U}$ & 0.781 & 0.665 & 26.2 & & 2.98 & 0.003 \\
\hline & M & 0.778 & 0.756 & 5.1 & 80.4 & 0.50 & 0.615 \\
\hline \multirow[t]{2}{*}{ N. of males } & $\mathrm{U}$ & 3.000 & 2.266 & 44.3 & & 5.95 & 0.000 \\
\hline & M & 2.909 & 2.892 & 1.0 & 97.7 & 0.10 & 0.923 \\
\hline \multirow{2}{*}{$\begin{array}{l}\text { N. of members with primary } \\
\text { education }\end{array}$} & $\mathrm{U}$ & 3.466 & 2.077 & 84.2 & & 10.75 & 0.000 \\
\hline & M & 3.403 & 3.475 & -4.3 & 94.9 & -0.35 & 0.723 \\
\hline \multirow{2}{*}{$\begin{array}{l}\text { N. of members with primary } \\
\text { education }\end{array}$} & $\mathrm{U}$ & 0.360 & 0.110 & 37.8 & & 5.49 & 0.000 \\
\hline & M & 0.330 & 0.232 & 14.8 & 61.0 & 1.25 & 0.212 \\
\hline \multirow[t]{2}{*}{ N. of sheep } & $\mathrm{U}$ & 3.169 & 1.810 & 14.5 & & 2.36 & 0.019 \\
\hline & M & 3.034 & 2.340 & 7.4 & 48.9 & 0.68 & 0.495 \\
\hline Having a bank account & $\mathrm{U}$ & 0.112 & 0.074 & 13.1 & & 1.64 & 0.101 \\
\hline & M & 0.102 & 0.095 & 2.6 & 80.6 & 0.23 & 0.816 \\
\hline Shock & $\mathrm{U}$ & 0.163 & 0.130 & 9.4 & & 1.14 & 0.256 \\
\hline & M & 0.153 & 0.190 & -10.3 & -10.4 & -0.91 & 0.365 \\
\hline
\end{tabular}

Source: Kagera Health and Development Survey, wave II (2004). 
Table A5 Balanced test of 2004 variables between households with unimodal versus bimodal migrants

\begin{tabular}{|c|c|c|c|c|}
\hline Variable & $\begin{array}{l}\text { Mean total } \\
\text { sample }\end{array}$ & $\begin{array}{l}\text { Mean sample with } \\
\text { unimodal migrants }\end{array}$ & $\begin{array}{l}\text { Mean sample with } \\
\text { bimodal migrants }\end{array}$ & $\begin{array}{l}\text { Difference unimodal - } \\
\text { bimodal }\end{array}$ \\
\hline \multirow[t]{2}{*}{ Age (HH head) } & 54.800 & 58.130 & 54.450 & 3.680 \\
\hline & $(15.600)$ & $(14.770)$ & $(15.670)$ & $(2.849)$ \\
\hline \multirow[t]{2}{*}{ Sq. Age (HH head) } & $3,245.300$ & $3,590.300$ & $3,209.800$ & 380.600 \\
\hline & $(1,718.200)$ & $(1,753.800)$ & $(1,713.600)$ & $(335.600)$ \\
\hline \multirow[t]{2}{*}{ Male (HH head) } & 0.660 & 0.700 & 0.656 & 0.044 \\
\hline & $(0.474)$ & $(0.466)$ & $(0.476)$ & $(0.090)$ \\
\hline \multirow[t]{2}{*}{ Married (HH head) } & 0.657 & 0.733 & 0.649 & 0.084 \\
\hline & $(0.475)$ & $(0.450)$ & $(0.478)$ & $(0.087)$ \\
\hline \multirow[t]{2}{*}{ Employee (HH head) } & 0.123 & 0.200 & 0.115 & 0.085 \\
\hline & $(0.329)$ & $(0.407)$ & $(0.320)$ & $(0.077)$ \\
\hline \multirow[t]{2}{*}{ Farmer own field (HH head) } & 0.897 & 0.900 & 0.897 & 0.003 \\
\hline & $(0.304)$ & $(0.305)$ & $(0.305)$ & $(0.059)$ \\
\hline \multirow[t]{2}{*}{ Businessman (HH head) } & 0.290 & 0.267 & 0.292 & $(0.025)$ \\
\hline & $(0.454)$ & $(0.450)$ & $(0.456)$ & $(0.086)$ \\
\hline \multirow[t]{2}{*}{ HH size } & 6.988 & 7.000 & 6.986 & 0.014 \\
\hline & $(3.117)$ & $(2.051)$ & $(3.210)$ & $(0.419)$ \\
\hline \multirow[t]{2}{*}{ N. children (<6years) } & 0.960 & 0.633 & 0.993 & $-0.360 *$ \\
\hline & $(1.013)$ & $(0.669)$ & (1.037) & $(0.136)$ \\
\hline \multirow[t]{2}{*}{ N. adults (>18years) } & 3.265 & 3.433 & 3.247 & 0.186 \\
\hline & $(1.463)$ & (1.104) & $(1.495)$ & $(0.220)$ \\
\hline \multirow[t]{2}{*}{ N. educated members } & 3.888 & 4.200 & 3.856 & 0.344 \\
\hline & $(2.066)$ & $(1.901)$ & $(2.083)$ & $(0.368)$ \\
\hline \multirow[t]{2}{*}{ N. farmers } & 4.760 & 5.367 & 4.698 & $0.669 *$ \\
\hline & $(2.424)$ & $(1.608)$ & $(2.487)$ & $(0.328)$ \\
\hline \multirow[t]{2}{*}{ Acre of own plots } & 4.705 & 6.530 & 4.516 & 2.014 \\
\hline & $(5.258)$ & $(11.060)$ & (4.229) & $(2.035)$ \\
\hline \multirow[t]{2}{*}{ N. cattle } & 1.150 & 1.833 & 1.079 & 0.754 \\
\hline & $(4.288)$ & $(5.730)$ & (4.118) & (1.074) \\
\hline \multirow[t]{2}{*}{ N. enterprises } & 0.648 & 0.800 & 0.632 & 0.168 \\
\hline & $(0.785)$ & $(0.925)$ & $(0.769)$ & $(0.175)$ \\
\hline \multirow[t]{2}{*}{ Toilet } & 0.969 & 0.933 & 0.973 & $(0.039)$ \\
\hline & $(0.174)$ & $(0.254)$ & $(0.164)$ & $(0.047)$ \\
\hline \multirow[t]{2}{*}{ Electricity } & 0.041 & 0.067 & 0.038 & 0.029 \\
\hline & $(0.197)$ & $(0.254)$ & $(0.191)$ & $(0.048)$ \\
\hline \multirow[t]{2}{*}{ Bank account } & 0.121 & 0.167 & 0.117 & 0.050 \\
\hline & $(0.327)$ & $(0.379)$ & $(0.322)$ & $(0.072)$ \\
\hline \multirow[t]{2}{*}{ Biharamulo } & 0.081 & 0.100 & 0.079 & 0.021 \\
\hline & $(0.273)$ & $(0.305)$ & $(0.270)$ & $(0.058)$ \\
\hline \multirow[t]{2}{*}{ Karagwe } & 0.134 & 0.167 & 0.131 & 0.036 \\
\hline & $(0.341)$ & $(0.379)$ & $(0.338)$ & $(0.072)$ \\
\hline Bukoba rural & 0.358 & 0.333 & 0.361 & $(0.028)$ \\
\hline & $(0.480)$ & $(0.479)$ & $(0.481)$ & $(0.092)$ \\
\hline Bukoba urban & 0.156 & 0.233 & 0.148 & 0.086 \\
\hline & $(0.363)$ & $(0.430)$ & $(0.355)$ & $(0.081)$ \\
\hline Ngara & 0.081 & 0.000 & 0.089 & $-0.0893 * * *$ \\
\hline & $(0.273)$ & 0.000 & $(0.286)$ & $(0.017)$ \\
\hline Muleba & 0.190 & 0.167 & 0.192 & $(0.026)$ \\
\hline & $(0.393)$ & $(0.379)$ & $(0.395)$ & $(0.073)$ \\
\hline Tot consumption pc (in TSh) & $358,868.600$ & $415,291.500$ & $353,051.800$ & $62,239.700$ \\
\hline & $(205,820.600)$ & $(203,655.300)$ & $(205,508.100)$ & $(39,085.100)$ \\
\hline Food consumption pc (in & $246,407.200$ & $274,520.000$ & $243,509.000$ & $31,011.000$ \\
\hline & $(133,862.800)$ & $(127,403.700)$ & $(134,386.000)$ & $(24,558.400)$ \\
\hline Observations & 325 & 30 & 295 & 325 \\
\hline
\end{tabular}


Table A6 Summary statistics of variables used for semi-experimental approach

\begin{tabular}{lcccc}
\hline & Mean & Std. Dev. & Min & Max \\
\hline Distance $(\mathrm{Km})$ & 279.738 & 459.533 & 0.010 & 1578.880 \\
Unimodal & 0.084 & 0.279 & 0 & 1 \\
Distance $(\mathrm{Km}) *$ Unimodal & 54.117 & 214.379 & 0 & 1323.130 \\
Diff acre of owned plot & 0.161 & 6.704 & -55.200 & 36.500 \\
Diff. number of owned cattle & 0.455 & 3.400 & -16.000 & 32.000 \\
Diff. toilet & -0.028 & 0.224 & -1 & 1 \\
Diff. electricity & 0.011 & 0.150 & -1 & 1 \\
Diff. number of enterprises & 0.140 & 1.024 & -3 & 5 \\
\hline
\end{tabular}

Observations 325

Source: Kagera Health and Development Survey, wave II (2004) and III (2010). 
Figure A1 Common support.

Source: authors' elaboration using Kagera Health and Development Survey, wave II (2004)

(a) Extended households

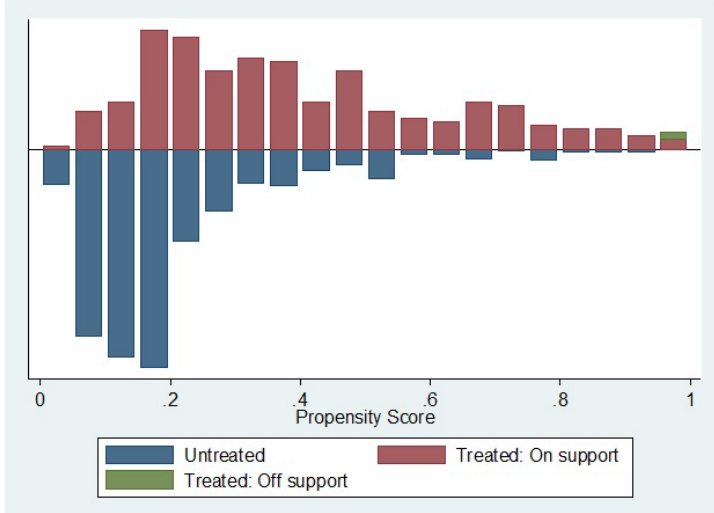

(b) Households with same head

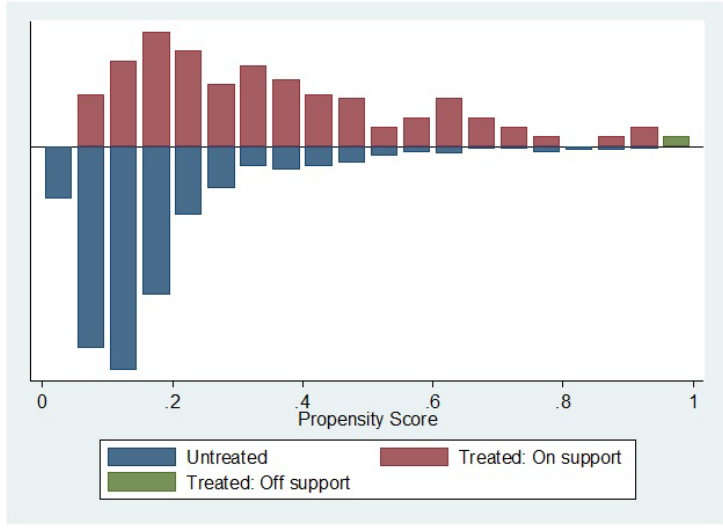

